\title{
Variability of Continental Riverine Freshwater and Nutrient Inputs into the North Sea for the Years 1977-2000 and Its
} Consequences for the Assessment of Eutrophication

\author{
Günther RADACH ${ }^{1 *}$ and Johannes Pätsch ${ }^{2}$ \\ ${ }^{1}$ Holunderweg $7 c, 22850$ Norderstedt, Germany \\ 2 Institut für Meereskunde, Bundesstrasse 53, 20146 Hamburg, Germany
}

\begin{abstract}
We determined the monthly and annual riverine freshwater, nitrogen $(\mathrm{N})$ and phosphorus $(\mathrm{P})$ loading into the North Sea from Belgium, The Netherlands, and Germany for the years 1977-2000. An average of $133 \mathrm{~km}^{3} \mathrm{yr}^{-1} \mathrm{of}_{\text {the }} 309 \mathrm{~km}^{3}$ $\mathrm{yr}^{-1}$ precipitation into the watershed is carried by the rivers into the sea. Total freshwater discharge fluctuates with a strong 6 $7 \mathrm{yr}$ periodicity, is strongly correlated with precipitation, and exhibits a slight long-term decrease. The temporal changes of regional patterns of precipitation lead to changing ratios of annual discharge of the western rivers compared to the eastern rivers, varying between 2.2 and 3.5. The long-term oscillations in discharge were more pronounced as discharge increased. The annual means of total and dissolved inorganic $N$ and $P$ loads were estimated to be 722 and $582 \mathrm{kt} \mathrm{N} \mathrm{yr}^{-1}$ and 48 and $26 \mathrm{kt}$

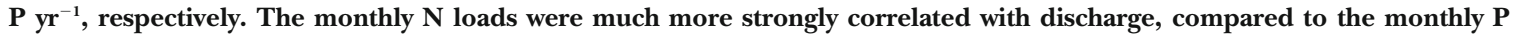
loads. Total $N$ and $P$ as well as dissolved inorganic $N$ also demonstrated a $6-7$ yr periodicity. The annual $N$ loads decreased by about $17 \mathrm{kt} \mathrm{N} \mathrm{yr}^{-1}$ from 1977 to 2000 . The total phosphorus and phosphate loads decreased from about 80 and $50 \mathrm{kt} \mathrm{P} \mathrm{yr}^{-1}$ in the 1980s to 25 and $12 \mathrm{kt} \mathrm{P} \mathrm{yr}^{-1}$, respectively, in the 1990s. The western rivers contributed the major part of the nutrient loads. The long-term oscillations in their nutrient loads were much more pronounced, compared to the eastern rivers. The area-specific loading rates estimated for all rivers are comparable to earlier estimates using shorter data records, smaller sample sizes, and a less complete watershed monitoring program. The monthly and annual average N:P ratios and their variability increased considerably for individual rivers during the study interval. These results confirm that the water quality of European continental rivers is strongly influenced by intense land use. They demonstrate the necessity for using long time series monitoring results to assess change and evaluate the effects of climate change on the North Sea coastal ecosystems, using ecosystem models on decadal time scales.
\end{abstract}

\section{Introduction}

Eutrophication has been recognized as a potential problem for several decades (Rhyther and Dunstan 1971; Rosenberg 1985). In a survey of the biogeochemical cycles of the world oceans' coastal zone, Jickells (1998) demonstrated that the pressures from the human populations around the coastal seas, such as habitat destruction, waste disposal, and intensive agriculture, are already fundamentally challenging the biogeochemical cycles in many areas. Based on projections for food production and wastewater effluents, Bouwman et al. (2005) predicted that the global river nitrogen (N) flux to coastal marine systems will increase by $13 \%$ in the coming three decades, which will lead to eutrophication problems. For Europe a decrease by $20 \%$ is projected for the $1995-2030$ period, but at present many coastal areas of the North Sea are highly eutrophic. Human activity has altered not only the discharge of nutrients but may also have

\footnotetext{
* Corresponding author; tele: +49(0)40-5294712; fax: +49(0)4042838-7485; e-mail: guenther.radach@wtnet.de
}

changed the carbon balance in the North Sea from net heterotrophic to net autotrophic (Kempe 1995).

The most eutrophic area in the North Sea is the continental coastal strip along Belgium, The Netherlands, Germany, and Denmark (Fig. 1). Nutrients enter the North Sea via various pathways. The Atlantic Ocean is the main natural source of nutrients, while rivers, the atmosphere, and diffusive and direct sources provide natural as well as anthropogenic inputs. The relative importance of the river inputs was under debate for a long time (Galloway et al. 1996; Howarth et al. 1996). The best way to determine the relative importance of the various inputs for the state of the coastal waters is to calculate nutrient budgets for the whole North Sea. Such budgets can be calculated from a model simulation as performed by Proctor et al. (2003). For this, it is essential that the nutrient inputs are introduced with sufficient accuracy. When Gazeau et al. (2004) attempted to establish a metabolic balance using the current database for European coastal seas, they failed, even for the North Sea. Obviously, the database has to be improved for this purpose. One important input parameter in budget- 


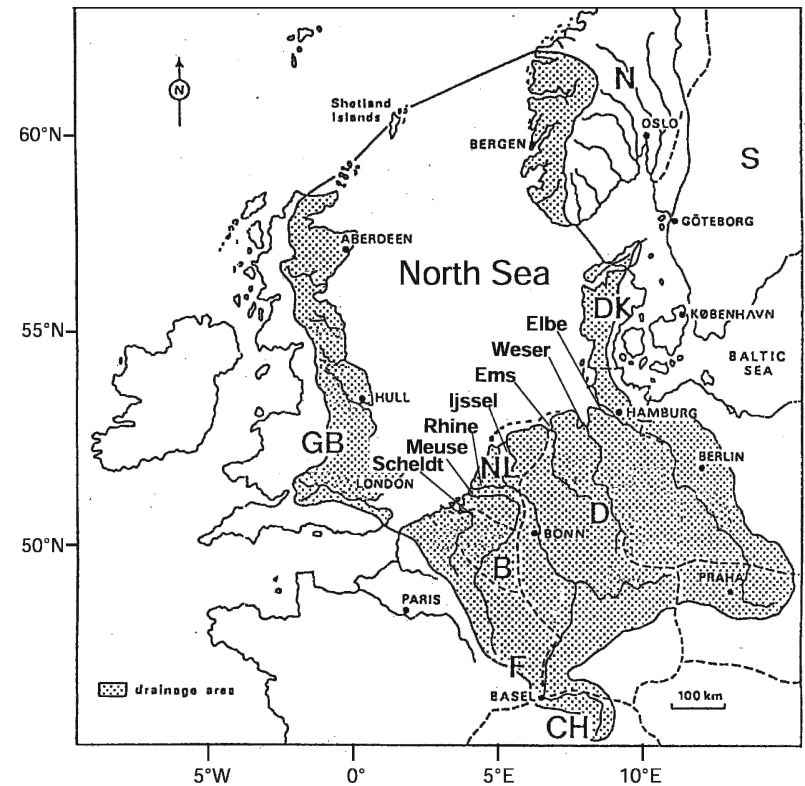

Fig. 1. Locations of the entries of the continental rivers into the North Sea and their catchment basins. Modified after Radach (1992; Fig. 2).

ing is the riverine nutrient flux into the North Sea, which will be the focus of this paper.

For the North Sea, Nelissen and Steffels (1988) set up the first nutrient budgets. They demonstrated the overwhelming importance of the riverine nutrient inputs into the continental coastal zone of the North Sea by using climatologically averaged annual river load estimates. Radach (1992) presented improved budgets, still using the climatologically averaged annual river loads estimated by Nelissen and Steffels (1988). No seasonal or interannual variability of the loads could be taken into account in these considerations due to the lack of data.

In coastal waters large temporal and spatial variability of loads imposes variability on the corresponding parameters of the coastal sea. Variability of human activity in combination with climate variability is the largest contribution to the variability of the ecologically important parameters in the rivers and coastal seas. Climatic variability over the North Atlantic acts in two ways on the North Sea: it determines the Atlantic inflow into the North Sea and governs the precipitation over continental Europe (Greatbatch 2000). It has a significant effect on river discharges and nutrient loads. It is still an open question how the regional patterns of precipitation and riverine nutrient loads are related to this atmospheric variability.

Long time series are necessary for assessing the relations between these agents and are finally becoming available. Data on freshwater discharge and nutrient concentrations in single rivers have been collected and made available during the last decades by many authorities in the countries bordering the North Sea. Calculations of nutrient loads for the continental rivers based on these data were performed in an attempt to simulate the eutrophication in coastal and central North Sea waters. Simulation models require input data for all rivers entering the North Sea. The modelling project ERSEM (Baretta et al. 1995; Baretta-Bekker and Baretta 1997) provided the most comprehensive data sets (Lenhart et al. 1996). These were also used in other model simulations for estimating nutrient loads to enable an assessment of the relative contributions of the single rivers to the eutrophication of the coastal sea and to compare these to other sources of nutrients (Lenhart et al. 1997; Pätsch and Radach 1997).

These comprehensive data sets of the continental riverine freshwater and nutrient inputs into the North Sea (Lenhart and Pätsch 2001) were extended up to the year 2000 by Pätsch and Lenhart (2004). Their new time series allow more realistic estimates of freshwater discharges and nutrient loads than were previously possible.

In this paper, time series of daily discharges and nutrient river loads from the European continental rivers for 1977-2000 are presented. Their characteristics are discussed on monthly, annual, and decadal time scales. The river loads are put in relation to other environmental variables such as rainfall and the North Atlantic Oscillation Index (NAOI). The analysis of the time series of precipitation in the catchment areas of the main rivers is used to supplement the interpretation. The area-related results for the individual rivers are compared with each other and with other watersheds. We discuss the consequences of the results on the assessment of eutrophication of the continental coastal waters.

\section{Materials and Methods}

\section{DATA SOURCES}

The raw data entering the load calculation are in all cases values of discharge and nutrient concentrations. We restrict our analysis to the observations of total nitrogen $(\mathrm{TN})$, nitrate or nitrate plus nitrite, ammonium, total phosphorus (TP), and orthophosphate as the main nutrients. Freshwater discharges were mostly sampled daily while concentrations were sampled weekly, biweekly, or monthly. In the latest report by Pätsch and Lenhart (2004) the river loads were presented for the years 1977 to 2002. These data can be downloaded from pub/data/ riverload at ftp.ifm.zmaw.de. Here we evaluate the time series until the end of the year 2000. The original data were kindly provided by the following 
TABLE 1. Available data sets for rainfall, freshwater discharge, total nitrogen (TN), dissolved inorganic nitrogen compounds (nitrate + nitrite, ammonia), total phosphorus (TP), and phosphate (DIP). Vrouwenzand indicates the Lake Ijssel inlet. The catchment areas of the outlets Haringvliet, Nieuwe Waterweg, and Nordzeekanaal are parts of the catchment area of the river Rhine, for which rain data are available.

\begin{tabular}{|c|c|c|c|c|c|c|c|}
\hline Rivers & Rainfall Data & Freshwater Discharge & $\mathrm{TN}$ & Nitrate + Nitrite & Ammonium & $\mathrm{TP}$ & DIP \\
\hline Elbe & $1977-2000$ & $1977-2000$ & $1978-2000$ & $1977-2000$ & $1977-2000$ & $1978-2000$ & 1977-2000 \\
\hline Ems & $1977-2000$ & $1977-2000$ & $1980-2000$ & $1977-2000$ & $1977-2000$ & $1977-2000$ & $1981-2000$ \\
\hline Haringvliet & 1977-2000 & 1977-2000 & $1977-2000$ & $1977-2000$ & $\begin{array}{l}1977-1994 \\
1998-2000\end{array}$ & $1977-2000$ & $1977-2000$ \\
\hline Nieuwe Waterweg & 1977-2000 & $1977-2000$ & $1977-2000$ & $1977-2000$ & $1977-2000$ & 1977-2000 & 1977-2000 \\
\hline Nordzeekanaal & 1977-2000 & $1977-2000$ & 1977-2000 & $1977-2000$ & $\begin{array}{l}1977-1994 \\
1998-2000\end{array}$ & 1977-2000 & 1977-2000 \\
\hline Vrouwenzand & no data & 1977-2000 & $1977-2000$ & $1977-2000$ & $\begin{array}{l}1977-1994 \\
1998-2000\end{array}$ & $1977-2000$ & 1977-2000 \\
\hline Weser & 1977-2000 & 1977-2000 & 1980-2000 & 1977-2000 & $1977-2000$ & $1977-2000$ & $\begin{array}{l}1981-1992 \\
1994-2000\end{array}$ \\
\hline
\end{tabular}

institutions: Wassergütestelle Elbe, Neßdeich 120121, 21129 Hamburg, Germany (www.arge-elbe.de); Bundesanstalt für Gewässerkunde, Hydrologische Datenbank HYDABA1, Am Mainzer Tor 1, Postfach 200253, 56002 Koblenz, Germany (www.bafg.de); Niedersächsischer Landesbetrieb für Wasserwirtschaft, Küsten- und Naturschutz (NLWKN), Betriebsstelle Hannover-Hildesheim, Aufgabenbereich 32: Oberirdische Gewässer, An der Scharlake 39, 31135 Hildesheim, Germany (www.nlwkn.de); and Rijkswaterstaat RIKZ/ITB, P.O. box 20907, 2500 EX DEN HAAG, The Netherlands (http:// www.rikz.nl). The availability of river data over time until 2000 is shown in Table 1.

All data for the river Elbe were provided by the Arbeitsgemeinschaft für die Reinhaltung der Elbe. The data were published in an annual series Wassergütedaten der Elbe as well as in special issues. The documents are available in the internet under www.arge-elbe.de. The discharge data represent daily measurements from the last tide-free gauge station at Neu Darchau at km 536. Until 1991 the concentration data were from weekly samples at the site Teufelsbrück ( $\mathrm{km} \mathrm{630)}$ just downstream of Hamburg harbour. Thereafter, the data stem from weekly samples at the sampling station Seemannshöft $(\mathrm{km} \mathrm{628)}$. At these two stations, the outlets of the big water treatment plant Köhlbrandshöft are not yet completely mixed with the Elbe water. Both sampling sites are well upstream of the tidal mixing

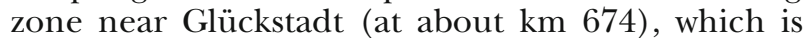
characterized by a chloride content of $150 \mathrm{mg} \mathrm{l}^{-1}$. Before 1993, the nutrient data were derived from individual samples; from 1994 onwards the data were taken from horizontal profile mixing probes. For the rivers Weser and Ems, the daily flow data were obtained at the last tide-free gauge stations Intschede and Herbrum, respectively, by the Bundesanstalt für Gewässerkunde in Koblenz. The data are regularly published in the annual series of the Deutsche Gewässerkundliche Jahrbücher. Information is also available in the internet under www.bafg.de. The concentration data for the same stations were provided by the Landesamt für Ökologie (LfO) in Hildesheim (Anonymous 1998). Information on the data is also published in the internet under www.nloe.de.

River inputs from the Dutch coast were supplied by Rijkswaterstaat in The Netherlands. Information on the data is provided by the series Jaarboek Monitoring Rijkswateren, for which general information is available in the internet under www. waterland.net/jmr. Since The Netherlands have established a dense network of channels for regulating the water flow and, especially, the water level throughout the country, it is not possible to trace back the input of a certain river, e.g., the Rhine. The data of The Netherlands' inlets contain concentration and discharge data right at the inlet. The river input data from the Belgian coast refer to the river Scheldt. The RIKZ in the Netherlands provided data at the Belgian-Dutch border at the location Schaar van Ouden Doel. The discharge data were available from 1977 onwards, and as daily values since 1990 . The concentration data were measured every 2 wk. Further details about data sources, frequency, and methods of riverine observations were given by Pätsch and Lenhart (2004).

Rain data were provided by the Deutscher Wetterdienst (Abteilung Hydrometeorologie) in Kaiserleistrasse 44, 63067 Offenbach, Germany (www.dwd.de), as monthly values of heights of precipitation for the catchment areas (Gebietsniederschlagshöhen) of the rivers Elbe, Weser, Ems, and Rhine. Multiplication of the monthly heights of precipitation $(\mathrm{mm})$ with the catchment areas $\left(\mathrm{km}^{2}\right)$ results in the total monthly amounts of precipitation within the catchment areas $\left(\mathrm{km}^{3}\right)$. Rain data for 
TABLE 2. Regressions for interpolating missing daily river load data: rivers, data gaps, years of data used for regressions, regression parameters X, Y, a, [in t/d] and b [non-dimensional] from $\mathrm{Y}=\mathrm{a}+\mathrm{bX}$, and regression coefficient $\mathrm{r}$ with lower and upper confidence limits $\mathrm{r}_{1}$ and $\mathrm{r}_{\mathrm{u}}$, with $99 \%$ probability. $\mathrm{TN}=$ total nitrogen, $\mathrm{TP}=$ total phosphorus, $\mathrm{DIN}=$ dissolved inorganic nitrogen, and $\mathrm{DIP}=$ dissolved inorganic phosphorus.

\begin{tabular}{|c|c|c|c|c|c|c|c|c|c|c|}
\hline River & Missing Years & $\begin{array}{l}\text { Data Used for } \\
\text { Regression from } \\
\text { Years }\end{array}$ & $\mathrm{y}$ & $\mathrm{x}$ & $\mathrm{a}$ & $\mathrm{b}$ & $\mathrm{r}$ & $\mathrm{r}_{1}$ & $r_{u}$ & $\begin{array}{c}\text { Number of } \\
\text { Data }\end{array}$ \\
\hline Elbe & 1977 & 1978-1982 & $\mathrm{TN}$ & $\mathrm{NO}_{3}$ & 148.3580 & 1.3495 & 0.9358 & 0.9269 & 0.9437 & 1461 \\
\hline Elbe & 1977 & 1978-1982 & $\mathrm{TP}$ & DIP & 6.0868 & 1.8420 & 0.6307 & 0.5882 & 0.6696 & 1461 \\
\hline Ems & 1977-1979 & 1980-1984 & $\mathrm{TN}$ & $\mathrm{NO}_{3}$ & 2.6589 & 1.3756 & 0.9842 & 0.9822 & 0.9860 & 1827 \\
\hline Ems & 1977-1980 & 1981-1985 & DIP & $\mathrm{TP}$ & 0.6012 & 0.2969 & 0.5568 & 0.5137 & 0.5971 & 1826 \\
\hline Weser & $1977-1979$ & 1980-1984 & $\mathrm{TN}$ & $\mathrm{NO}_{3}$ & 22.5478 & 1.2355 & 0.9717 & 0.9681 & 0.9749 & 1827 \\
\hline Weser & 1977-1980, 1993 & 1981-1985 & DIP & $\mathrm{TP}$ & 1.8504 & 0.5818 & 0.8345 & 0.8152 & 0.8519 & 1826 \\
\hline Haringvliet & $1995-1997$ & 1990-1994 & $\mathrm{NH}_{4}$ & $\mathrm{TN}$ & -0.3866 & 0.0502 & 0.9581 & 0.9529 & 0.9628 & 1826 \\
\hline Nordzeekanaal & 1995-1997 & 1990-1994 & $\mathrm{NH}_{4}$ & $\mathrm{TN}$ & -0.9721 & 0.1248 & 0.7856 & 0.7614 & 0.8077 & 1826 \\
\hline Scheldt & 1995-1997 & 1990-1994 & $\mathrm{NH}_{4}$ & $\mathrm{TN}$ & -3.9729 & 0.1891 & 0.8600 & 0.8434 & 0.8749 & 1826 \\
\hline Vrouwenzand & 1995-1997 & 1990-1994 & $\mathrm{NH}_{4}$ & $\mathrm{TN}$ & -0.2957 & 0.0198 & 0.8084 & 0.7864 & 0.8283 & 1826 \\
\hline
\end{tabular}

the drainage areas of the other rivers, like Meuse and Scheldt, were not available.

The time series for the NAOI were taken from the web pages provided by James W. Hurrell, National Center for Atmospheric Research, U.K. (www.cru. uea.ac.uk/cru/data/nao.htm) and Jeffrey C. Rogers, Ohio State University, USA (www-bprc.mps. ohio-state.edu).

\section{Methods}

We used the double linear interpolation method for calculating loads from discharge and concentration data (Pätsch and Lenhart 2004). The method produces linearly interpolated concentration values $C^{L I}{ }_{i}$, as well as discharge values $Q^{L I}{ }_{i}$ for every day. For the $i$-th day the load is then $L_{i}=C^{L I}{ }_{i} \times Q^{L I}{ }_{i}$. The formula for the annual load $L$ sums up the daily loads. Then

$$
L=\sum_{i=1}^{k} L_{i},
$$

where $k$ is the number of days per year. The linear interpolation leaves the observations unaltered and fills the gaps by interpolated values.

Observational gaps of 1-3 yr exist for 10 of 56 time series (Table 1). We have closed these gaps by using the linear regressions listed in Table 2, where the regression parameters including confidence limits (CL) are given for the 10 regressions made. For the rivers Elbe, Ems and Weser the river loads of $\mathrm{TN}$ and nitrate correlate very well $(\mathrm{r}>0.92, \mathrm{p}=$ 0.01 ), and $\mathrm{TN}$ loads were estimated for the missing years by the regression on nitrate loads. For the same rivers TP is missing for a few years. Although TP and dissolved inorganic phosphorus (DIP) have sometimes rather different annual cycles, TP loads correlate quite satisfactorily with loads of DIP; the regression of loads of TP on loads of DIP could be used for the Elbe $(r=0.63, p=0.01)$ and the regression of DIP loads on TP loads was used for rivers Ems $(r=0.56, p=0.01)$ and Weser $(r=0.83$, $\mathrm{p}=0.01)$. For four Dutch outlets, the loads of ammonium had to be estimated for the interval 1995-1997, which was achieved by regressing ammonium loads on TN loads $(\mathrm{r}>0.78, \mathrm{p}=0.01)$.

There is a shift in the TP data, showing different regimes before and after 1991. As we are not the data originators, but collected the data from the different authorities, we must rely on the publications about the data and the reported methods used to obtain them. We checked the data as far as possible and did not find any flaws. We also observed a shift related to the DIP loads for several rivers since 1991. For the river Elbe, the reunification of Germany certainly had consequences for the river loads. For other rivers, we have no idea why this change occurred.

Three aspects have to be regarded when estimating the amounts of nutrients entering the sea. The observations of freshwater discharges and nutrient concentrations used for estimating the river loads are usually not measured at the same location. Since the North Sea is a tidally influenced shelf sea, the inflowing rivers show typical estuarine characteristics. Any measurement monitoring the outflowing river waters has to avoid observations in mixing water masses. The discharge data entering this study were usually measured at the last tide-free gauge station, except for the Dutch data. The concentration measurements were made more towards the river mouth, in contrast to the position of the discharge measurements. In order to get a sample of pure river water, it is taken at low tide so that mixing processes can be considered to have only a minor influence. In this way the concentration measurement represents the state of the river water entering the North Sea as well as possible.

A second aspect of the data is that tributaries entering the river downstream of the observational 
TABLE 3. Catchment areas and mean annual discharge of European continental rivers entering the North Sea. Discharge values for the continental rivers are according to our own calculations.

\begin{tabular}{|c|c|c|c|c|}
\hline River & $\begin{array}{l}\text { Catchment } \\
\text { Area }\left(\mathrm{km}^{2}\right)\end{array}$ & $\begin{array}{l}\text { Percentage of Total } \\
\text { North Sea Catchment } \\
\text { Area }(\%)\end{array}$ & $\begin{array}{c}\text { Mean Annual } \\
\text { Discharge }\left(\mathrm{km}^{3} \mathrm{yr}^{-1}\right)\end{array}$ & $\begin{array}{l}\text { Mean Annual Precipitation } \\
\text { in Catchment Area }\left(\mathrm{km}^{3} \mathrm{yr}^{-1}\right)\end{array}$ \\
\hline From German and Danish coasts, thereof by river & $219,900^{\mathrm{b}}$ & 26.1 & $32^{\mathrm{b}}$ & no data \\
\hline Elbe & 148,268 a & 17.6 & 22.5 & 95.8 \\
\hline Ems & $12,300^{\mathrm{a}}$ & 1.5 & 2.7 & 10.0 \\
\hline Weser & $46,303^{\mathrm{a}}$ & 5.5 & 10.5 & 36.1 \\
\hline From Dutch and Belgian coasts, thereof by river & $221,400^{\mathrm{b}}$ & 26.3 & $91-97^{\mathrm{b}}$ & $167.3^{\mathrm{c}}$ \\
\hline Nieuwe Waterweg & no data ${ }^{\text {d }}$ & no data ${ }^{\mathrm{d}}$ & 45.4 & no data ${ }^{e}$ \\
\hline Haringvliet/Meuse & no data ${ }^{\mathrm{d}}$ & no data ${ }^{\mathrm{d}}$ & 26.1 & no data ${ }^{e}$ \\
\hline Nordzeekanaal & no data ${ }^{\mathrm{d}}$ & no data ${ }^{\mathrm{d}}$ & 7.3 & no data ${ }^{e}$ \\
\hline Lake Ijssel/Vrouwenzand & no data & no data & 18.9 & no data \\
\hline $\begin{array}{l}\text { Catchment area of continental rivers } \\
\text { (including Scheldt }+ \text { Meuse) }\end{array}$ & 428,503 & 50.9 & 133.3 & $309.2^{c}$ \\
\hline Total catchment area of North Sea & $841,500^{\mathrm{b}}$ & 100.0 & $296-354^{\text {b }}$ & no data \\
\hline
\end{tabular}

${ }^{\mathrm{a}}$ Catchment area from Lozan and Kausch (1996).

${ }^{\mathrm{b}}$ Catchment area from OSPAR (2000).

${ }^{c}$ Without precipitation in catchment areas of Lake Ijssel, Meuse, and Scheldt.

${ }^{\mathrm{d}}$ The outlets Haringvliet, Nieuwe Waterweg, and Nordzeekanaal discharge water from the catchment areas of the rivers Rhine $\left(185,000 \mathrm{~km}^{2}=22 \%\right)$, Meuse $\left(16,100 \mathrm{~km}^{2}=1.9 \%\right)$, and Scheldt $\left(20,300 \mathrm{~km}^{2}=2.4 \%\right)$.

${ }^{\mathrm{e}}$ The catchment area of the river Rhine, for which rain data are available, is part of the catchment areas of the outlets Haringvliet, Nieuwe Waterweg, and Nordzeekanaal.

site may contribute considerable amounts of water. The Elbe discharge as observed at Neu Darchau (at $191 \mathrm{~km}$ before entering the North Sea) is probably increased by about $21 \%$ by the discharge of the tributaries further downstream. The discharges for the rivers Ems and Weser are estimated to increase by $30 \%$ and $19 \%$, respectively (Pätsch and Lenhart 2004). These additional amounts of freshwater would increase the total amount of continental freshwater discharge by about $5 \%$. We have not applied these factors in our calculations (Tables 3, 4 , and 5), because they are rather uncertain. For all other rivers the discharges were estimated directly at their entrance into the North Sea.

A third aspect is that the calculated loads have to pass the estuaries before they enter the North Sea, as the measuring stations are intentionally positioned upstream of the estuary. The discharged nutrients are used within the estuaries, and the loads will not remain as they were estimated. This retention of nutrients in estuaries cannot be ignored. The conversion of the nutrients from inorganic to organic forms as well as the opposite pathway during their passage through the rivers and estuaries downstream from the observational stations should be considered in any calculations of riverine inputs to the North Sea. Nixon et al. (1996) found that, on average, about half of the $\mathrm{N}$ inputs from rivers is consumed within the estuaries and suggested that this effect can be accounted for by applying a factor of 0.45 to the loads calculated in the usual way. Denitrification is a major sink for $\mathrm{N}$ on the continental shelves (Seitzinger and Giblin
1996) and in the estuaries (Jickells 1998). It is still under debate how to quantify this loss of river borne $\mathrm{N}$ before it enters the coastal sea (Van Beusekom et al. 1999). In Tables 4 and 5 the nutrient loads given are not yet reduced by a retention factor.

\section{Results}

Freshwater Discharges and Precipitation in Catchment Areas of the Continental Rivers

Figure 2 presents the time series of the cumulative discharge of the rivers Ems, Nordzeekanaal, Scheldt, Weser, Vrouwenzand, Elbe, Haringfliet, and Nieuwe Waterweg (in this sequence from bottom to top). A negative long-term trend of about $-1.22 \mathrm{~km}^{3} \mathrm{yr}^{-1}$ exists in the time series of total annual discharge values. Superimposed on this trend, an oscillation appears with a period of 6$7 \mathrm{yr}$. This periodicity was maintained when the annual integration was started in July instead of January. Four maxima (182, 177, 161, $\left.140 \mathrm{~km}^{3} \mathrm{yr}^{-1}\right)$, decreasing in magnitude, are following each other every 6-7 yr. The average of all annual discharge values is $133 \mathrm{~km}^{3} \mathrm{yr}^{-1}$, with a standard deviation of $26 \mathrm{~km}^{3} \mathrm{yr}^{-1}$.

The average annual precipitation of $309 \mathrm{~km}^{3} \mathrm{yr}^{-1}$, summed over the catchment areas of the rivers Ems, Weser, Elbe, and Rhine, is more than twice the amount of water discharged by all rivers. The total average annual precipitation, including the watersheds of the rivers Scheldt and Meuse, would be even larger. The time series of cumulative annual discharge (lower curve) is similar to the time series 
TABLE 4. Annual precipitation over the catchment areas of the rivers Ems, Weser, Elbe, and Rhine, and river discharges of freshwater and nutrient loads for total and dissolved inorganic nitrogen and phosphorus for the years 1977-2000, summed over all continental rivers. The numbers in parentheses are the standard deviations.

\begin{tabular}{|c|c|c|c|c|c|c|}
\hline Year & $\begin{array}{l}\text { Precipitation } \\
\left(\mathrm{km}^{3} \mathrm{yr}^{-1}\right)\end{array}$ & $\begin{array}{c}\text { Freshwater } \\
\text { Discharge }\left(\mathrm{km}^{3} \mathrm{yr}^{-1}\right)\end{array}$ & $\begin{array}{l}\text { Total Nitrogen } \\
\left(10^{3} \mathrm{t} \mathrm{N} \mathrm{yr}^{-1}\right)\end{array}$ & $\begin{array}{l}\text { Nitrate }+ \text { Ammonium } \\
\quad\left(10^{3} \mathrm{t} \mathrm{N} \mathrm{yr}^{-1}\right)\end{array}$ & $\begin{array}{l}\text { Total Phosphorus } \\
\quad\left(10^{3} \mathrm{t} \mathrm{P} \mathrm{yr}^{-1}\right)\end{array}$ & $\begin{array}{l}\text { Phosphate } \\
\left(10^{3} \mathrm{tP} \mathrm{yr}^{-1}\right)\end{array}$ \\
\hline 1977 & 317 & 124 & 735 & 579 & 62 & 36 \\
\hline 1978 & 304 & 131 & 730 & 564 & 61 & 38 \\
\hline 1979 & 309 & 148 & 902 & 710 & 75 & 44 \\
\hline 1980 & 319 & 154 & 907 & 712 & 77 & 47 \\
\hline 1981 & 383 & 182 & 1,067 & 857 & 78 & 48 \\
\hline 1982 & 271 & 148 & 811 & 647 & 62 & 39 \\
\hline 1983 & 300 & 144 & 794 & 636 & 61 & 39 \\
\hline 1984 & 324 & 141 & 830 & 674 & 63 & 40 \\
\hline 1985 & 270 & 114 & 700 & 551 & 54 & 35 \\
\hline 1986 & 337 & 140 & 840 & 695 & 60 & 36 \\
\hline 1987 & 339 & 177 & 1,051 & 875 & 59 & 32 \\
\hline 1988 & 329 & 166 & 932 & 759 & 63 & 33 \\
\hline 1989 & 261 & 104 & 595 & 486 & 39 & 22 \\
\hline 1990 & 297 & 98 & 529 & 435 & 30 & 16 \\
\hline 1991 & 236 & 91 & 480 & 401 & 25 & 12 \\
\hline 1992 & 306 & 111 & 590 & 483 & 29 & 14 \\
\hline 1993 & 334 & 117 & 607 & 498 & 30 & 14 \\
\hline 1994 & 343 & 157 & 837 & 672 & 52 & 15 \\
\hline 1995 & 337 & 161 & 801 & 630 & 44 & 15 \\
\hline 1996 & 258 & 96 & 461 & 370 & 27 & 11 \\
\hline 1997 & 272 & 101 & 457 & 375 & 22 & 10 \\
\hline 1998 & 351 & 121 & 579 & 469 & 27 & 12 \\
\hline 1999 & 314 & 140 & 560 & 449 & 27 & 12 \\
\hline 2000 & 311 & 133 & 537 & 439 & 25 & 12 \\
\hline Average & 309 (34) & $133(26)$ & $722(182)$ & $582(145)$ & 48 (19) & $26(14)$ \\
\hline
\end{tabular}

of cumulative annual precipitation (upper curve). Precipitation also shows the same periodicity of $6-$ $7 \mathrm{yr}$ as discharge does. The cross-correlation is best for a time lag of zero, with $\mathrm{r}=0.73$ (CL 0.35, 0.90 for $99 \%$ probability). The corresponding time series of monthly data (not shown) correlate less well, but are best correlated at a time lag of $-1 \mathrm{mo}$, with a correlation coefficient $r=0.35$ (CL $0.20,0.48$ on the $99 \%$ level). Freshwater river discharges and precipitation correlate very well for annual data, but less well for monthly data.

The annual cycles of monthly total continental freshwater discharge exhibit a large variability, because they are strongly influenced by the precipitation pattern over Europe, the melting cycles of snow and glaciers, and the construction of channels in The Netherlands. Contrary to the annual amounts, no long-term trend is obvious in the monthly integrated values of discharge (Fig. 3). There is a slight indication that the minimum values in summer decrease in the long term.

The ratio of the freshwater discharges from the western, mostly channelled, rivers (Nordzeekanaal, Scheldt, Vrouwenzand, Haringvliet, Nieuwe Waterweg) discharging into the Southern Bight, to those of the eastern rivers (Ems, Weser, Elbe), discharging

TABLE 5. Watershed related values of precipitation, freshwater discharge, total nitrogen (TN), dissolved inorganic nitrogen (DIN), total phosphorus (TP), and dissolved inorganic phosphorus (DIP), mean ( \pm standard deviation), and molar N:P ratios of total and dissolved materials. For precipitation the river Rhine watershed area of $185,000 \mathrm{~km}^{2}$ without the catchment areas of Ijssel, Meuse, and Scheldt must be used, so the total area is $392,103 \mathrm{~km}^{2}$ for precipitation considerations.

\begin{tabular}{|c|c|c|c|c|c|c|}
\hline Parameter & Unit & Elbe & Weser & Ems & $\begin{array}{c}\text { Rhine + Meuse + } \\
\text { Scheldt }\end{array}$ & Sum for All Rivers \\
\hline Catchment area & $\mathrm{km}^{2}$ & 148,500 & 46,303 & 12,300 & 221,400 & 428,503 \\
\hline Precipitation & $\mathrm{m} \mathrm{yr}^{-1}$ & $0.645(0.087)$ & $0.779(0.100)$ & $0.811(0.109)$ & $0.904(0.098)$ & $0.789(0.088)$ \\
\hline Freshwater discharge & $\mathrm{m} \mathrm{yr}{ }^{-1}$ & $0.151(0.042)$ & $0.227(0.061)$ & $0.217(0.058)$ & $0.441(0.081)$ & $0.311(0.061)$ \\
\hline $\begin{array}{l}\text { Freshwater discharge/ } \\
\text { precipitation }\end{array}$ & $\%$ & 23 & 29 & 27 & 49 & 39 \\
\hline $\mathrm{TN}$ & $\mathrm{kg} \mathrm{N} \mathrm{km}^{-2} \mathrm{yr}^{-1}$ & $1,015(342)$ & $1,469(430)$ & $1,660(453)$ & $2,181(522)$ & $1,685(424)$ \\
\hline DIN & $\mathrm{kg} \mathrm{N} \mathrm{km}^{-2} \mathrm{yr}^{-1}$ & $819(295)$ & $1,222(363)$ & $1,391(387)$ & $1,746(408)$ & $1,358(339)$ \\
\hline TP & $\mathrm{kg} \mathrm{P} \mathrm{km}{ }^{-2} \mathrm{yr}^{-1}$ & $50(20)$ & $80(39)$ & $66(31)$ & $163(64)$ & $112(44)$ \\
\hline DIP & $\mathrm{kg} \mathrm{P} \mathrm{km}^{-2} \mathrm{yr}^{-1}$ & $21(11)$ & $47(33)$ & $24(18)$ & $94(47)$ & $62(32)$ \\
\hline TN:TP & $\operatorname{mol~N}(\operatorname{mol~P})^{-1}$ & 45.4 & 40.8 & 55.7 & 29.6 & 33.3 \\
\hline DIN:DIP & $\mathrm{mol} \mathrm{N}(\mathrm{mol} \mathrm{P})^{-1}$ & 87.6 & 57.8 & 126.2 & 41.1 & 48.9 \\
\hline
\end{tabular}




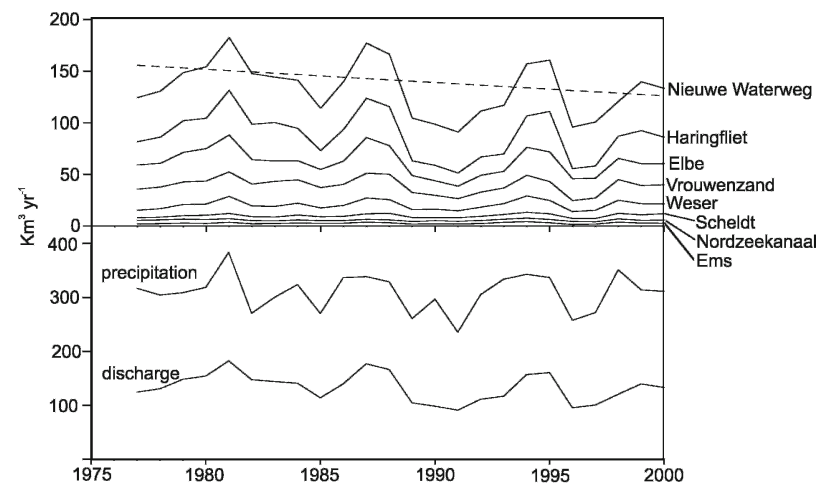

Fig. 2. Annual amounts of total freshwater discharges of the continental rivers, cumulative over the rivers Ems, Nordzeekanaal, Scheldt, Weser, Vrouwenzand, Elbe, Haringfliet, and Nieuwe Waterweg (from bottom to top); dashed line: linear trend of total discharge; and annual amounts of precipitation for the catchment areas of the continental rivers Ems, Weser, Elbe, and Rhine, and total discharge.

into the German Bight, varies considerably over the course of the $24 \mathrm{yr}$ between 2.2 and 3.5. This indicates varying regional patterns of precipitation and melting of ice and snow over continental Europe on time scales of 6-7 yr (Fig. 3). The low ratios occur at maximum annual discharge rates and the highest at the minimum rates, except for the last period since 1996.

\section{NUTRIENT INPUTS}

Monthly TN, DIN, TP, and DIP loads show clear similarities but also strong differences in their longterm developments (Fig. 4). They are related to highly variable discharge, which is clearly seen for

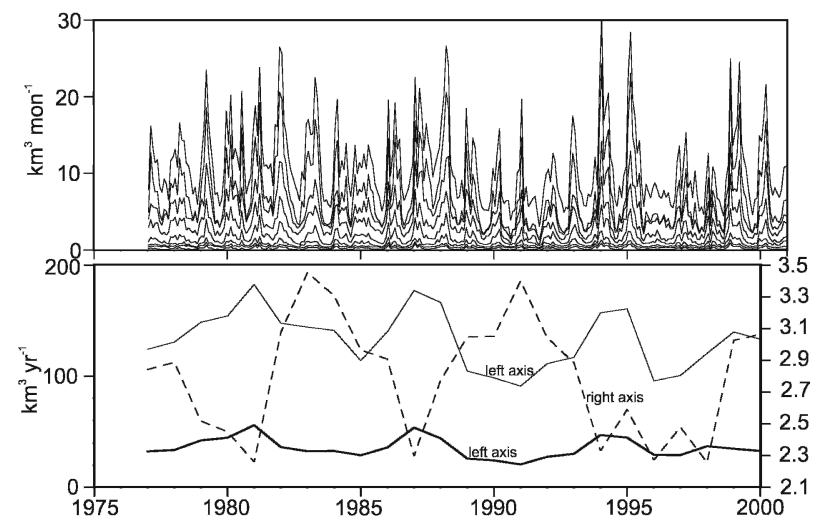

Fig. 3. Monthly values of total freshwater discharges of the continental rivers, cumulative over the rivers Ems, Nordzeekanaal, Scheldt, Weser, Vrouwenzand, Elbe, Haringfliet, and Nieuwe Waterweg (from bottom to top); annual amounts of freshwater discharges of the eastern (thick line) and of all (thin line) continental rivers, cumulative over the rivers (left axis), and ratio of annual amounts of freshwater discharges of the western and eastern continental rivers (dashed line, right axis).

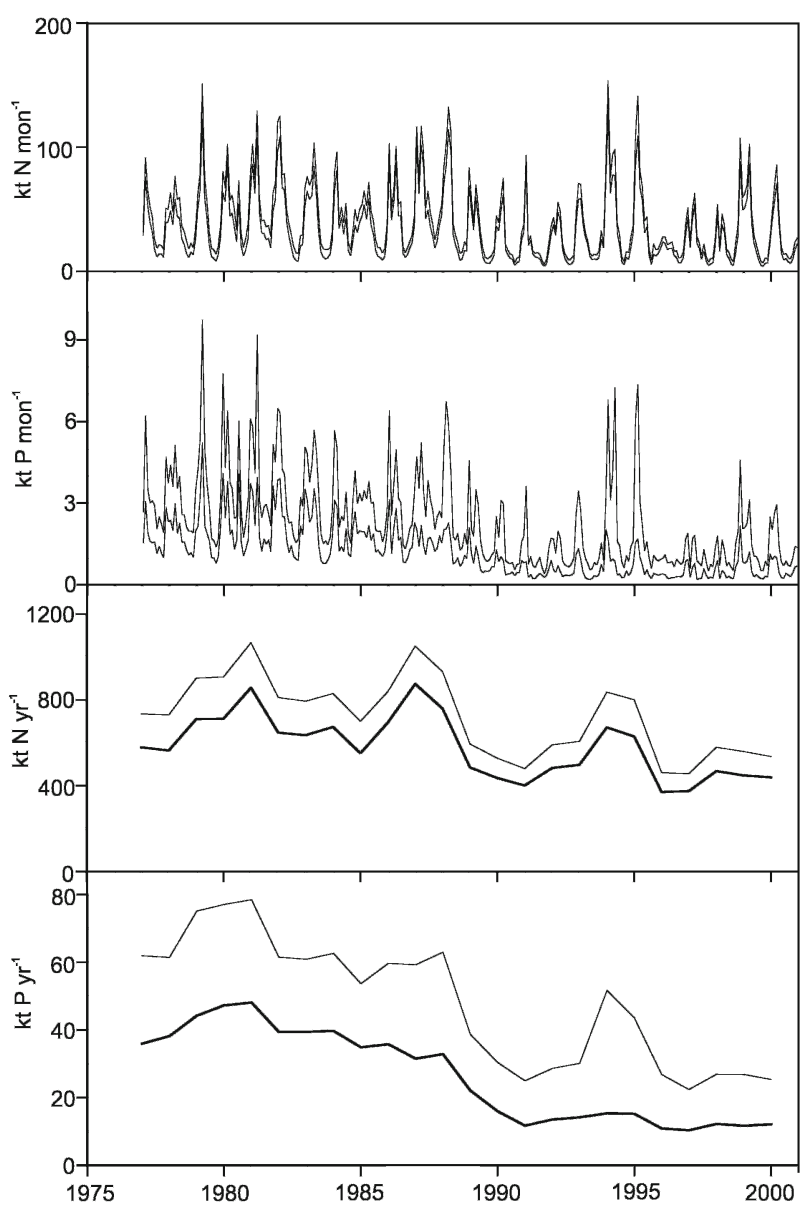

Fig. 4. Monthly amounts of total nitrogen (upper line) and dissolved inorganic nitrogen (lower line) and total phosphorus (upper line) and phosphate (lower line); and annual amounts of total nitrogen (thin line) and dissolved inorganic nitrogen (thick line) and total phosphorus (thin line) and phosphate (thick line). The loads were summed over all rivers (Ems, Nordzeekanaal, Scheldt, Weser, Vrouwenzand, Elbe, Haringfliet, and Nieuwe Waterweg).

both $\mathrm{N}$ and $\mathrm{P}$ when visually comparing Figs. 3 and 4 . The monthly nutrient values strongly correlated with discharge rates for $\mathrm{N}$ and less strongly for $\mathrm{P}$. Large monthly inputs occurred during spring in the years 1994 and 1995. But in 1996, for example, the monthly total discharge values were small all yearround, and the nutrient inputs were accordingly low.

The variability of riverine nutrient input is largest on small time scales ( $\leq$ months), which is not shown here. The time series of monthly $\mathrm{TN}$ and DIN show strongly varying seasonal cycles, and no clear overall decrease is visible. TP and - even more DIP show a downward trend. Their maxima occurred during the period 1979-1981 and loads have decreased since then, except for TP during the years 1994 and 1995. These years brought extraor- 
dinarily high freshwater discharges. They were the cause for high $\mathrm{N}$ loads in these years. TP increased during these two years to threefold of the average level during the 1990s, phosphate values increased only twofold (Fig. 4). Nitrate concentration is more closely related to freshwater discharge than phosphate is, as was shown by correlating these nutrient concentrations in the river Elbe with Elbe freshwater discharge (e.g., Hickel et al. 1993).

Annual loads of TN, TP, DIN, and DIP fractions declined over the period of $24 \mathrm{yr}$ in the rivers Elbe, Weser, Ems, and Rhine (including Meuse and Scheldt). The annual amounts of all four compounds exhibit the cyclic long-term behavior (Fig. 4) that was also apparent in the freshwater discharges (Fig. 2). Summed over all continental rivers all four nutrient parameters show maxima every 6-7 yr. On the decadal time scale, only phosphate shows nearly no change in the annual loads during the mid 1990s (Fig. 4).

The annual loads of the nutrients, summed over all rivers, are given in Table 4 together with the corresponding freshwater discharge and precipitation within the respective catchment areas. The averages and standard deviations of the precipitation, water discharge, and annual loads are also given (last line). Averaged over the $24 \mathrm{yr}$ from 1977 to 2000 , the mean nutrient load of TN is $722 \mathrm{kt} \mathrm{N}$ $\mathrm{yr}^{-1}$; the corresponding value for TP is $48 \mathrm{kt} \mathrm{P} \mathrm{yr}^{-1}$, with standard deviations of the annual values of $182 \mathrm{kt} \mathrm{N} \mathrm{yr}^{-1}$ and $19 \mathrm{kt} \mathrm{P} \mathrm{yr}^{-1}$, respectively (Table 4, last line). For annual $\mathrm{N}$ loads the standard deviation is about $25 \%$ of the means, whereas for $\mathrm{P}$ it is $40-$ $50 \%$ of the mean values. For comparison, the annual standard deviation for freshwater discharges is $20 \%$ of the mean value. The DIN load accounts for $81 \%$ of the TN load. For P, the DIP load is $54 \%$ of the total load. When considering the statistics, it should be noted that the TP and TN loads have undergone strong decreases, from 60-70 kt P yr${ }^{-1}$ and $800 \mathrm{kt} \mathrm{N} \mathrm{yr}^{-1}$ in the late $1970 \mathrm{~s}$ to about $25 \mathrm{kt} \mathrm{P}$ $\mathrm{yr}^{-1}$ and $550 \mathrm{kt} \mathrm{N} \mathrm{yr}^{-1}$, respectively, in the late 1990s.

TN, TP, and DIN also showed the 6-7 yearly periodic signal for the nutrient loads of eastern and western rivers regarded separately. The nutrient fractions in the eastern and western rivers change in relation to each other in the same way as the relative fractions of discharges. Figure 5 shows the time series of the annual values of TN, TP, DIN, and DIP for the eastern (Ems, Weser, Elbe) and western (Nordzeekanaal, Scheldt, Vrouwenzand, Haringvliet, Nieuwe Waterweg) rivers. For all four compounds, the western rivers contribute the major proportion of the loads discharged into the North Sea, and the long-term oscillations are more pronounced for them compared to the eastern contributions. The clear signal for the western rivers was

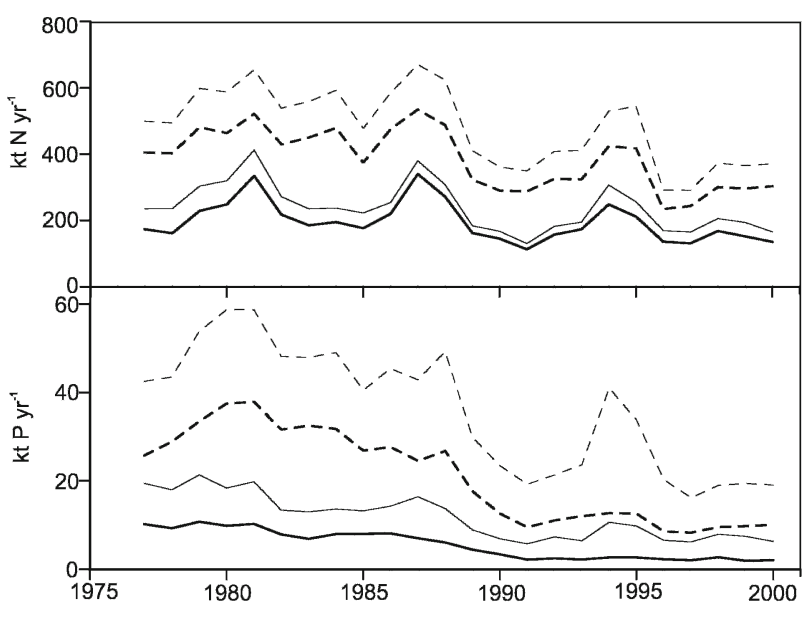

Fig. 5. Annual loads of total nitrogen (thin lines) and dissolved inorganic nitrogen (thick lines) for the eastern rivers (full lines) and the western rivers (dashed lines); total phosphorus (thin lines) and phosphate (thick lines) for the eastern rivers (full lines) and the western rivers (dashed lines).

disturbed in the early 1980 s, whereas the eastern rivers do not show such irregularities.

\section{Relations between Environmental Parameters \\ Correlations between Rainfall, Riverine Freshwater Discharges, and NAOI}

Cross-correlation analysis supports the results of Fig. 2 that total annual precipitation and riverine freshwater discharge are closely related. As freshwater discharge determines the nutrient loads into the North Sea, nutrient discharge, and especially $\mathrm{N}$ discharge, appear to be largely controlled by precipitation. Recent precipitation anomalies over Europe are associated with the upward trend of NAOI (Fig. 6) during the past several decades (Greatbatch 2000). Figs. 2 and 4 suggest that the long-term low frequent oscillation of 6-7 yr duration may be connected to the NAOI via precipitation. We have cross-correlated the annual NAOI as well as the seasonal NAOIs (using both data sets, from Hurrell and from Rogers) with the annual precipitation for the total catchment areas (Ems, Weser, Elbe, and Rhine), for the eastern (Ems, Weser, Elbe) and western (Rhine) catchment areas, as well as with the seasonal precipitation (total, eastern, and western areas). Altogether we did 26 cross-correlations that were not significant, except for one case.

The annual NAOI correlates neither with annual precipitation nor with annual river discharge, neither for the total nor for the eastern or western precipitation or catchment areas, respectively. Nor do the seasonal time series of NAOI yield any significant correlation with seasonal precipitation, except for spring in the eastern area; spring NAOI 


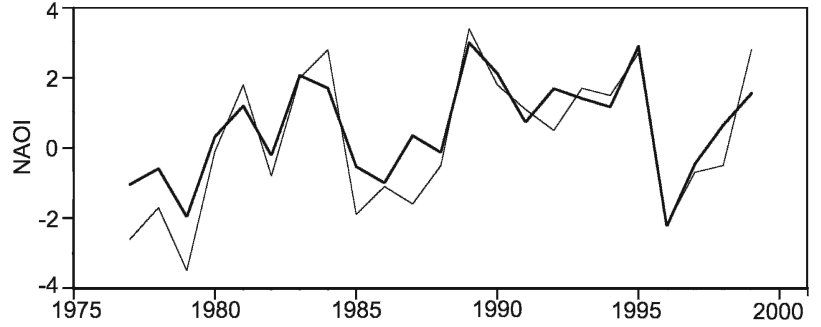

Fig. 6. Winterly North Atlantic Oscillation Index (NAOI) for the years 1977-1999, calculated from monthly values as provided by J. W. Hurrell (www.cru.uea.ac.uk/cru/data/nao.htm; thick line) and J. C. Rogers (www-bprc.mps.ohio-state.edu; thin line).

correlates negatively $(\mathrm{r}=-0.57, \mathrm{CL}-0.85,-0.04$ for $99 \%$ ) with the precipitation from the eastern catchment area that occurred $1 \mathrm{yr}$ later. The expected correlation between winter NAOI and winter total, eastern, or western rainfall remained slightly insignificant $(\mathrm{r}=0.51$ for total winter precipitation, with $\mathrm{CL}-0.02,0.81)$. These results are discussed below in connection with the findings of climate research.

\section{N:P Ratio}

The ratio of $\mathrm{N}$ and $\mathrm{P}$ inputs is important for the way the coastal ecosystem reacts to the inputs, for example with respect to changes in species composition and increasing primary production (Hickel 1998; Radach 1998). The N:P ratios are given here as $\mathrm{tN} / \mathrm{tP}$, to correspond with the previous calculations; e.g., the value $7.23(\mathrm{tN} / \mathrm{tP})$ is equivalent to the molar Redfield ratio of $16(\operatorname{mol~N} / \mathrm{mol} \mathrm{P})$. Because $\mathrm{P}$ loads decreased more rapidly than $\mathrm{N}$ loads, the mean $\mathrm{N}: \mathrm{P}$ ratios on the basis of monthly as well as annual loads have increased significantly during the considered decades in the individual rivers, both for the total and dissolved inorganic fractions. The N:P ratios calculated from monthly loads show strong annual variability (Fig. 7); the mean values increased over time, both for the total and dissolved inorganic fractions. The ratios of TN to TP ranged between 10 and 40; the ratios for the dissolved inorganic fractions ranged between 10 and 110. At the same time the range of variability has strongly increased over the years, much more strongly than the annual mean values did, both for total and dissolved inorganic matter. From 1977 to 1986 the N:P ratio of the dissolved inorganic fraction ranged between 10 and 40 . The range has more than doubled in the years from 1987 until 2000.

Annual N:P ratios (Fig. 8) derived from annual loads smooth out the high variability of monthly N:P ratios for total as well as for dissolved inorganic matter (Fig. 7). The annual ratios of total matter varied between 12 and 21. For dissolved inorganic

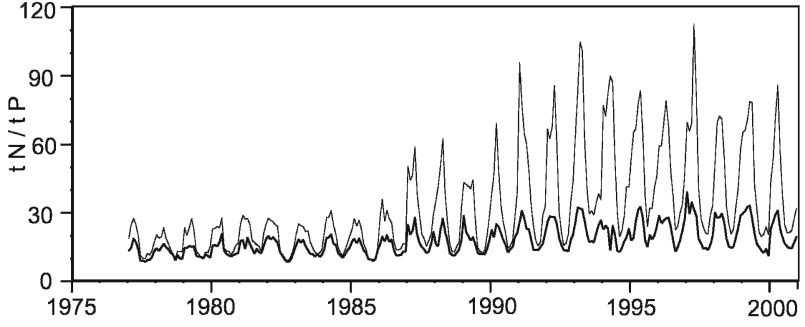

Fig. 7. N:P ratios of total nitrogen and phosphorus (lower, thick curve) and dissolved inorganic nitrogen and phosphorus (upper, thin curve), as ratios from monthly loads (summed over all rivers). The value 7.23 (TN:TP) is equivalent to the molar Redfield ratio of $16 \mathrm{~mol} \mathrm{~N}(\mathrm{~mol} \mathrm{P})^{-1}$.

matter they remained relatively small (about 15-18) during 1977-1985, but increased up to values around 40 during 1993-2000.

The N:P ratios for different rivers differed distinctly, as can be seen from Fig. 9. As an example, we contrasted the time series of $\mathrm{N}: \mathrm{P}$ ratios of monthly loads for the rivers Elbe and Nieuwe Waterweg. The N:P ratio of total matter for the river Elbe shows lower variability until 1986 and stronger variability over the rest of the time interval. The corresponding time series for river Nieuwe Waterweg showed regular small variability (range 815) until 1991, changing thereafter to increasing annual amplitudes (range 8-30). The ratio of monthly values of dissolved inorganic nutrients for the Elbe remained below 50 until 1986, but increased thereafter to annual maximum values between 70 and 180 . The ratio for the Nieuwe Waterweg started to increase strongly 4 yr later, and the ratios are much smaller than for the Elbe, namely 35 to 50 . In all four time series, a visible change appeared from 1987 onwards.

The main pulses occurred at different times within the years for both rivers. In 1995 two events in the $\mathrm{N}: \mathrm{P}$ ratio are recognizable for dissolved inorganic matter in Nieuwe Waterweg, with maximum $\mathrm{N}: \mathrm{P}=45$, whereas river Elbe had only one high maximum of $\mathrm{N}: \mathrm{P}=175$. In 1991, the event

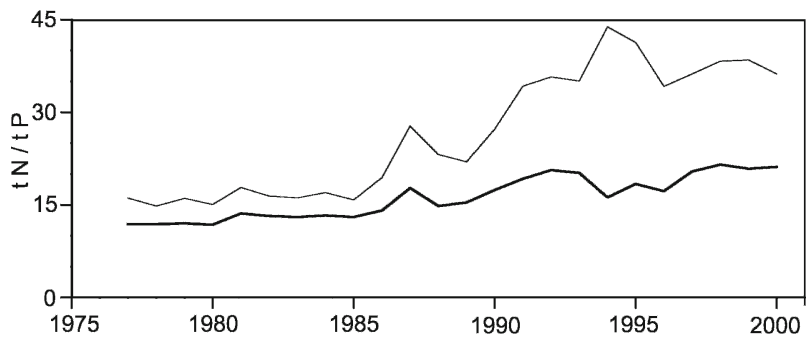

Fig. 8. N:P ratios of total nitrogen and phosphorus (lower, thick curve) and dissolved inorganic nitrogen and phosphorus (upper, thin curve), as ratios from annual loads (summed over all rivers). 


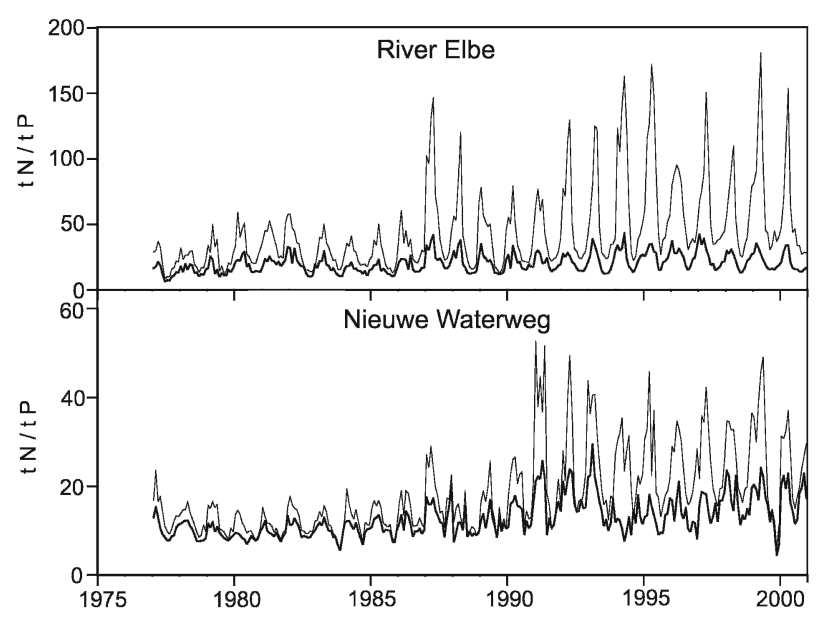

Fig. 9. N:P ratios of total and dissolved inorganic nitrogen and phosphorus, as monthly loads for the rivers Elbe Rhine (Nieuwe Waterweg). The upper, thin curve in both panels is for dissolved inorganic material.

structure as well as the absolute values of the $\mathrm{N}: \mathrm{P}$ ratios are similar for both rivers. The N:P ratios of the annual loads (not shown) mask these differences and exhibit rather similar evolutions of the $\mathrm{N}: \mathrm{P}$ ratios for summed dissolved inorganic nutrients, as shown in Fig. 8.

\section{WATERShed Properties}

Table 5 gives the 24-yr means and standard deviations of the fluxes related to the watersheds. The mean annual precipitation flux of $0.789 \mathrm{~m} \mathrm{yr}^{-1}$ hides the large differences between the rivers Elbe $\left(0.645 \mathrm{~m} \mathrm{yr}^{-1}\right)$ and Rhine $\left(0.904 \mathrm{~m} \mathrm{yr}^{-1}\right)$. Annual river discharges behave accordingly. The mean annual discharge value of $0.311 \mathrm{~m} \mathrm{yr}^{-1}$ is mostly determined by the river Rhine discharge of $0.441 \mathrm{~m}$ $\mathrm{yr}^{-1}$. The river Rhine discharge accounts for $49 \%$ of the precipitation in its watershed, whereas the river Elbe discharges only $23 \%$ of the precipitation in its watershed. When including the tributaries of river Elbe downstream of the sampling site, the percentage for the river Elbe would increase to about $28 \%$.

The 24-yr average fluxes of TN per area were very high $\left(1685 \pm 424 \mathrm{~kg} \mathrm{~N} \mathrm{~km}{ }^{-2} \mathrm{yr}^{-1}\right)$. The river Rhine discharged $2181 \pm 522 \mathrm{~kg} \mathrm{~N} \mathrm{~km}^{-2} \mathrm{yr}^{-1}$ on average, more than twice as much as the river Elbe (1015 \pm $342 \mathrm{~kg} \mathrm{~N} \mathrm{~km}{ }^{-2} \mathrm{yr}^{-1}$ ). All considered watersheds are highly anthropogenically disturbed ( $\mathrm{N}$ flux $>$ $1000 \mathrm{~kg} \mathrm{~N} \mathrm{~km}^{-2} \mathrm{yr}^{-1}$ ). The dissolved fraction DIN makes up 80-84\% of TN flux per area. The fluxes of TN and DIN decreased from the late 1970s to the late 1990s from about 790 and $620 \mathrm{~kg} \mathrm{~N} \mathrm{~km}^{-2} \mathrm{yr}^{-1}$ to about 530 and $490 \mathrm{~kg} \mathrm{~N} \mathrm{~km}^{-2} \mathrm{yr}^{-1}$ (3-yr means), respectively.

The mean TP and DIP fluxes were $112 \pm 44$ and $62 \pm 32 \mathrm{~kg} \mathrm{P} \mathrm{km}^{-2} \mathrm{yr}^{-1}$, mainly determined by the river Rhine fluxes of $163 \pm 64$ and $94 \pm 47 \mathrm{~kg} \mathrm{P}$ $\mathrm{km}^{-2} \mathrm{yr}^{-1}$, respectively. The $\mathrm{P}$ fluxes decreased strongly over the $24 \mathrm{yr}$, from about 66 and $39 \mathrm{~kg} \mathrm{P}$ $\mathrm{km}^{-2} \mathrm{yr}^{-1}$ of TP and DIP to 25 and $11 \mathrm{~kg} \mathrm{P} \mathrm{km}{ }^{-2}$ $\mathrm{yr}^{-1}$, respectively.

The molar N:P ratio of total matter summed over all rivers is 33.3 (Table 5), which is close to the value of 28 given by Howarth et al. (1996) for the corresponding region. The four watersheds behave differently. The N:P ratio ranged from 29.6 (Rhine) to 55.7 (Ems). The values are higher for inorganic dissolved material ( $\mathrm{N}: \mathrm{P}=41.1$ to 126.2$)$, indicating a relatively small amount of phosphate $(\mathrm{N}: \mathrm{P}>16)$ entering from the watersheds, especially for the watersheds of the rivers Ems $(\mathrm{N}: \mathrm{P}=126.2)$ and Elbe $(\mathrm{N}: \mathrm{P}=87.6)$. Thus, in all four rivers algal growth was $\mathrm{P}$ limited. This has also been shown to be the case for most North American and European watersheds (Table 2 in Howarth et al. 1996).

\section{Discussion}

The 24-yr time series we have compiled have a temporal resolution that enables analyses on time scales of months, years, and decades. Our results contribute to (time-dependent) budgeting of nutrients in the North Sea, to the comparison of watershed properties of the rivers Elbe, Weser, Ems, and Rhine with one another and with other watersheds, and to the assessment of eutrophication in the receiving coastal waters of the North Sea. These three aspects are discussed here.

\section{Riverine InPuts in ReLATiOn TO Other Budget Contributions to the North SEA}

Budgets for the North Sea were developed and steadily improved for water and the nutrients $\mathrm{N}$ and $\mathrm{P}$ over the last two decades (Nelissen and Steffels 1988; Radach and Lenhart 1995; OSPAR 2000; Thomas et al. 2006). Numerous estimates for the individual nutrient inputs from the nations bordering the North Sea were included in the budgets; e.g., the nutrient loadings to coastal waters of Norway by Ibrekk (1991) and to those of the U.K. by Littlewood et al. (1998).

The catchment area for the Greater North Sea is about $841,500 \mathrm{~km}^{2}$ (OSPAR 2000), providing a total freshwater discharge of 294-354 km $\mathrm{km}^{3}$. For comparison, the catchment area of the Baltic Sea provides a net freshwater supply of $470 \mathrm{~km}^{3} \mathrm{yr}^{-1}$; its catchment area of $1,650,000 \mathrm{~km}^{2}$ is twice as large as that of the North Sea (OSPAR 2000). According to our calculations annual total freshwater discharge from the main continental rivers of the North Sea varies between 91 and $182 \mathrm{~km}^{3} \mathrm{yr}^{-1}$, with a mean of $133 \mathrm{~km}^{3} \mathrm{yr}^{-1}$ (Fig. 2 and Table 4). The continental freshwater river input provides about $30-51 \%$ of the 
total amount of freshwater river discharge into the North Sea. The rivers deliver very different amounts of freshwater to the North Sea (Fig. 2 and Table 3). The largest contributions come from the rivers Rhine (Nieuwe Waterweg, Haringvliet, and Nordzeekanaal) and Elbe. The amounts of freshwater discharge are mainly determined by the sizes of the catchment areas (Table 3).

Mean net precipitation over the North Sea amounts to $50-100 \mathrm{~km}^{3} \mathrm{yr}^{-1}$ according to Carlson (1986) and $131 \mathrm{~km}^{3} \mathrm{yr}^{-1}$ according to an analysis by ECMWF (European Centre for Medium-range Weather Forecasts, Reading, U.K.) data by Damm (1997). The total freshwater input of $895-955 \mathrm{~km}^{3}$ $\mathrm{yr}^{-1}$, consisting of precipitation over the North Sea, the freshwater input from rivers, and the outflow from the Baltic Sea, is small in relation to the volume of $47,000 \mathrm{~km}^{3}$ of the Greater North Sea (delimited by $62^{\circ} \mathrm{N}, 5^{\circ} \mathrm{W}$ ). It is also small in relation to the inflows of North Atlantic water at the northern boundaries of about $44,150 \mathrm{~km}^{3} \mathrm{yr}^{-1}$ (1.4 Sv) and to the outflow at the northern boundary of the Norwegian Trench, which is of the same magnitude $\left(47,300 \mathrm{~km}^{3} \mathrm{yr}^{-1}=1.5 \mathrm{~Sv}\right.$; Fig. 2.14 in OSPAR 2000). Although the total freshwater input is even smaller than the order of magnitude of the uncertainty of the inflow and outflow estimates for seawater (Radach and Lenhart 1995), the riverine inputs of nutrients and their temporal and spatial variabilities are very important for the coastal subregions of the North Sea, because the currents keep them near the coasts.

Our new estimate of the riverine input of $\mathrm{TN}$ into the continental coastal zone amounts to an average of $722 \mathrm{kt} \mathrm{N} \mathrm{yr}{ }^{-1}$, including $582 \mathrm{kt} \mathrm{N} \mathrm{yr}^{-1}$ of DIN (Table 4). Our estimate for $\mathrm{N}$ nutrient input by the continental rivers is slightly higher than the $550 \mathrm{kt}$ $\mathrm{N} \mathrm{yr}{ }^{-1}$ given by the North Sea Task Force (1993); it is about half of the $1400 \mathrm{kt} \mathrm{N} \mathrm{yr}^{-1}$ estimated by OSPAR (2000) for all rivers entering the North Sea. The budget formulated by OSPAR (2000) includes, in addition to river inputs, $\mathrm{N}$ inputs from the atmosphere of about $350 \mathrm{kt} \mathrm{N} \mathrm{yr}{ }^{-1}$. Possibly, another $2700 \mathrm{kt} \mathrm{N} \mathrm{yr}^{-1}$ are gained by algal fixation,

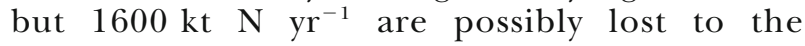
atmosphere by denitrification (OSPAR 2000). Howarth et al. (1996) estimated the total input of $\mathrm{N}$ from land into the whole North Sea to be $1220 \mathrm{kt} \mathrm{N}$ $\mathrm{yr}^{-1}$, while OSPAR (2000) gave a value of 916-928 kt $\mathrm{N} \mathrm{yr}^{-1}$ for the year 1996, including the English Channel, Kattegat, and Skagerrak. A recent compilation gives $761 \mathrm{kt} \mathrm{N} \mathrm{yr}^{-1}$ for the year 2000 (EEA 2005), which is comparable to our value for the share of the continental rivers of $537 \mathrm{kt} \mathrm{N} \mathrm{yr}^{-1}$ for the year 2000 (Table 4). Our estimate for TP of $48 \mathrm{kt} \mathrm{P} \mathrm{yr}^{-1}$ for the continental rivers is comparable to the value of $66 \mathrm{kt} \mathrm{P} \mathrm{yr}^{-1}$ given by OSPAR (2000) and $99 \mathrm{kt} \mathrm{P} \mathrm{yr}^{-1}$ estimated by Howarth et al. (1996), both values are given for all rivers entering the North Sea.

All of these values for riverine inputs are small compared to the advective inflows and outflows of the North Sea, which are about 10 times as large (OSPAR 2000). Recently, nutrient budgets were formulated by Thomas et al. (2006), using results that were obtained with an advanced and regionally extended version of the ecosystem model ERSEM (Pätsch and Radach 1997; Heath et al. 2002). Thomas et al. (2006) assumed a riverine input of $\mathrm{TN}$ of $757 \mathrm{kt} \mathrm{N} \mathrm{yr}^{-1}\left(54,071 \times 10^{6} \mathrm{~mol} \mathrm{yr}^{-1}\right)$ and a TP input of $46 \mathrm{kt} \mathrm{P} \mathrm{yr}^{-1}\left(1469 \times 10^{6} \mathrm{~mol} \mathrm{yr}^{-1}\right)$, making use of our river input time series. The river inputs make up only $9.4 \%$ and $4.3 \%$ for $\mathrm{N}$ and $\mathrm{P}$, respectively, compared to simulated advective inflows and outflows.

The large inflows and outflows across the northern boundaries are hardly relevant for the continental coastal zone (Radach and Lenhart 1995). Since the riverine inputs are concentrated in the continental coastal zone of about 50 to $100 \mathrm{~km}$ width, their effect is very strong in this area (Radach 1992). The molar N:P ratios for the total fractions of riverine inputs have increased from 10 to 20 during the period 1977-1986 to 15 to 30 from 1992 to 2000. Observations of nutrient concentrations in the coastal waters, for instance at Helgoland Roads (German Bight), have shown that the temporal development of riverine inputs was imposed on the receiving coastal waters (Fock 2003). The strong changes of N:P ratios in the sea over the last decades were attributed to the change of nutrient inputs during that time (Radach et al. 1990; Hickel et al. 1992; Hickel 1998). This had severe consequences for the coastal ecosystem, e.g., a drastic change in algal species composition (Van Beusekom and DielChristiansen 1994). It seems that the enhanced nutrient supply by the rivers leads to increased primary production in the coastal waters and, especially, in the Wadden Seas, where DIP acts as the limiting nutrient (Van Beusekom et al. 2005).

The long-term trends of the nutrient loads of the continental rivers and their effects on the coastal waters have been recognized and discussed in many papers (Radach 1992; Sündermann et al. 1996; Visser et al. 1996; Grimvall et al. 2000; Van Beusekom et al. 2005). The periodicity of 6-7 yr that is superimposed on the long-term trends, was not noticed so far, at least to our knowledge. This may be due to the fact that often the time series were averaged by running means over 3-5 yr (Sündermann et al. 1996; Visser et al. 1996). Visser et al. (1996) performed spectral analyses of the several time series of observations in the waters of the continental coast of the North Sea. They 
obtained significant periods only in the time series from Helgoland Roads in the range of 6-7 yr for salinity (6.6 yr), chlorophyll (6.2 yr), nitrate (7.4 yr), and silicate (6.8 yr). Although they used the load data from the rivers Elbe and Rhine for their interpretation, they did not analyze them spectrally. Periodicities of several years also seem to occur for rivers in other continents. The Mississippi River nitrate load seems to follow a 5-6 yr cycle (McIsaac et al. 2002).

Several long-term data sets have become available for the North Sea that may be used for timedependent budgeting. Littlewood et al. (1998) provided time series of estimated annual river mass loads of DIN, TP, and DIP for the years 1975-1995 as sums for all U.K. rivers discharging into the North Sea. Heath et al. (2002) fed their simulations with loads of specific years for the single U.K. rivers. For the Baltic outflow into the North Sea more information on time-dependent nutrient loads have become available, because of the intensive work on the eutrophication of the Baltic Sea (Wulff et al. 2001). Stalnacke et al. (2003) presented time series of river loads for rivers discharging into the Bay of Riga (Baltic Sea) for the period 1987-1998, which reflect the drastic reduction of fertilizers in the Baltic states Estonia, Latvia, and Lithuania. All of these time series of river loads are important building blocks for establishing time-dependent budgets of nutrients in the continental coastal zone. They can be used as forcing functions for ecological simulation models (e.g., Pätsch and Radach 1997; Heath et al. 2002; Moll and Radach 2003; Radach and Moll 2006), driven in combination by both anthropogenic and climatic forcing, over decades.

\section{Comparison of Watershed Properties}

Our 24-yr mean fluxes of TN per area for the continental rivers were $1685 \pm 424 \mathrm{~kg} \mathrm{~N} \mathrm{~km}^{-2} \mathrm{yr}^{-1}$, while Howarth et al. (1996) gave $1450 \mathrm{~kg} \mathrm{~N} \mathrm{~km}{ }^{-2}$ $\mathrm{yr}^{-1}$ as the mean flux for the corresponding area. Assuming a mean anthropogenic $\mathrm{N}$ input of $7044 \mathrm{~kg} \mathrm{~N} \mathrm{~km} \mathrm{kr}^{-1}$ into the watersheds of the North Sea (Table 4 in Howarth et al. 1996), the European continental rivers would transport $24 \%$ of this total into the sea, according to our estimates.

Compared with other rivers in Europe and around the North Atlantic, the continental N fluxes per area, which we derived from our load estimates, are large and the watersheds of these rivers are highly disturbed $\left(>1000 \mathrm{~kg} \mathrm{~N} \mathrm{~km}^{-2} \mathrm{yr}^{-1}\right)$. According to a recent compilation by the EEA (2005), in Europe the North Sea catchment areas provide the highest loads per area (about $1400 \mathrm{~kg} \mathrm{~N} \mathrm{~km}^{-2} \mathrm{yr}^{-1}$, $100 \mathrm{~kg} \mathrm{P} \mathrm{km}{ }^{-2} \mathrm{yr}^{-1}$ ), when compared to the Baltic
Sea catchment area (about $500 \mathrm{~kg} \mathrm{~N} \mathrm{~km}^{-2} \mathrm{yr}^{-1}$, $25 \mathrm{~kg} \mathrm{P} \mathrm{km} \mathrm{km}^{-2}$ ) and Danube catchment area (about $900 \mathrm{~kg} \mathrm{~N} \mathrm{~km}^{-2} \mathrm{yr}^{-1}, 80 \mathrm{~kg} \mathrm{P} \mathrm{km}^{-2} \mathrm{yr}^{-1}$ ).

Of the European rivers Daugave, Axios, Danube, Vistula, Odra, Po, Elbe, Weser, Rhine, and Ems, the highest TN loads were discharged by the river Po (about $3600 \mathrm{~kg} \mathrm{~N} \mathrm{~km}^{-2} \mathrm{yr}^{-1}$ ), followed by Ems and Rhine (each about $2900 \mathrm{~kg} \mathrm{~N} \mathrm{~km} \mathrm{kr}^{-1}$ ), Weser (about $1900 \mathrm{~kg} \mathrm{~N} \mathrm{~km} \mathrm{yr}^{-1}$ ), and Elbe (about $\left.1600 \mathrm{~kg} \mathrm{~N} \mathrm{~km}{ }^{-2} \mathrm{yr}^{-1}\right)$. These estimates were presented by EEA (2005); they were obtained with the process-based river model MONERIS (Behrendt 2004) and are considerably higher than our estimates for the rivers Ems, Weser, Elbe, and Rhine (Table 4). According to EEA (2005), the areaspecific $\mathrm{N}$ loads in north-western Europe are double (or more) than those in the Scandinavian countries. Total area-specific $\mathrm{N}$ loads vary by a factor of 5 for large European river catchments. The principal source for $\mathrm{N}$ pollution in European waters is the runoff from agricultural land, contributing typically about $50-80 \%$ of the total load. With increasing human activity, especially more intensive agriculture, the total area-specific loads of $\mathrm{N}$ increased (EEA 2005).

Our average TP flux of $112 \pm 44 \mathrm{~kg} \mathrm{P} \mathrm{km}{ }^{-2} \mathrm{yr}^{-1}$ for the continental watersheds is similar to the value of $117 \mathrm{~kg} \mathrm{P} \mathrm{km}^{-2} \mathrm{yr}^{-1}$ given by Howarth et al. (1996) for the whole of the North Sea watersheds. In comparison, using the model MONERIS, for $\mathrm{P}$ the largest area-specific loads of European rivers were calculated for the central Balkan river Axios (about $300 \mathrm{~kg} \mathrm{P} \mathrm{km}{ }^{-2} \mathrm{yr}^{-1}$, due to point sources) and for

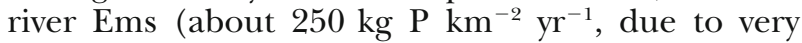
intensive agriculture). Estimates for area-specific $\mathrm{P}$ loads of the rivers Rhine $\left(130 \mathrm{~kg} \mathrm{P} \mathrm{km} \mathrm{km}^{-2} \mathrm{yr}^{-1}\right.$, Weser (100 kg P km ${ }^{-2} \mathrm{yr}^{-1}$ ), and Elbe (80 $\mathrm{kg} \mathrm{P} \mathrm{km}^{-2}$ $\mathrm{yr}^{-1}$ ) were also given by EEA (2005). Each of these is higher than our corresponding estimate. For $\mathrm{P}$, point sources such as households and industry are still the main contributors (EEA 2005).

Our results for riverine $\mathrm{N}$ discharge are higher than have been calculated for any other watersheds discharging into the North Atlantic Ocean (Fig. 2 in Howarth et al. 1996), even higher than those from the northwest coast of Europe $\left(1300 \mathrm{~kg} \mathrm{~N} \mathrm{~km}^{-2}\right.$ $\mathrm{yr}^{-1}$ ) and the northeast coast of the United States $\left(1070 \mathrm{~kg} \mathrm{~N} \mathrm{~km} \mathrm{Ng}^{-1}\right)$. All other large U.S. rivers carry less N. The nitrate flux of the Mississippi River varied between 200 and $500 \mathrm{~kg} \mathrm{~N} \mathrm{~km}^{-2} \mathrm{yr}^{-1}$ during the last two decades (McIsaac et al. 2002). The area related fluxes of the continental rivers for $\mathrm{P}$ are also very high in comparison to other Atlantic watersheds (Fig. 2 in Howarth et al. 1996), but lower than those for the northeast coast of the U.S. (139 kg P $\mathrm{km}^{-2} \mathrm{yr}^{-1}$ ) and the Amazon basin (236 kg $\mathrm{P} \mathrm{km}{ }^{-2}$ $\left.\mathrm{yr}^{-1}\right)$. 


\section{Influence of NAO ON The Precipitation PATtern}

The nutrient concentrations in the North Sea are determined by a number of factors, the most important of which are the Atlantic inflow, riverine inputs, and atmospheric inputs (OSPAR 2000). The latter two input pathways are unidirectional (although, after conversion by the ecosystem, there may also be fluxes back into the atmosphere, e.g., by outgassing of $\mathrm{N}_{2}$ through denitrification). All of these inputs are influenced by the northern hemispheric weather regime. Since the mid 1990s it has become clear that seasonal cycles of climate variables can no longer be assumed stationary for longer time scales (Dickson et al. 1988, 1996; Hurrell 1995). The North Atlantic Oscillation (NAO) is the dominant mode of climate variability in the area of the North Atlantic. Regional temperatures, precipitation, as well as wind speed and direction, over northern Europe are strongly influenced by the NAO on a decadal time scale, as was reviewed by Hurrell (1995). It has been shown that winters with high NAOI are associated with drier conditions over much of central and southern Europe and wetter than normal conditions over Scandinavia. The resulting precipitation pattern shows especially reduced precipitation over the Alps. Increased snowfall over the Alps can be associated with a return of NAOI to lower values (Hurrell and Van Loon 1997). The latter authors compared the precipitation anomalies of 14 winters (1981-1994) as departures from the 1951-1980 mean. The zero deviation contour runs across southern Germany, separating regions of more precipitation to the north and of less precipitation to the south. According to these results, the river Rhine, and perhaps also the river Elbe, should be more strongly influenced by the regions of lower precipitation than the rivers Ems and Weser.

Our linear correlation analysis of the time series of precipitation, freshwater discharges, and nutrient loads was not able to show a clear relationship with NAO. How do our results fit to those of Hurrell (1995)? When looking closer at the findings by Hurrell (1995) and others, it appears that the reason why we did not get clear correlations may lie in the fact that the signature of the NAO is strongly regional. Hurrell (1995) selected winters with high NAOI $(1983,1989,1990,1992,1993)$ and winters with low NAOI (1979, 1985, 1986, 1987, 1988). He then calculated the mean vertically integrated total moisture transport from ECMWF analyses for both sets of these years. A significant reduction of the total atmospheric moisture transport occurs over parts of southern Europe and the Mediterranean. During high NAOI winters, drier conditions occur over much of central and southern
Europe. Long-term station records of wintertime precipitation support the findings, but for our catchment regions the only station given by Hurrell (1995) is Frankfurt-Main, where a weak correlation between precipitation and winterly NAOI was established ( $\mathrm{r}=-0.19, \mathrm{p}=0.05)$.

It seems that the reason for the missing correlations between winter precipitation and NAOI in the considered catchment areas arises from the fact that the rivers run through regions in which the influence of NAO changes. Our correlation analysis cannot capture that proportion of the variations in precipitation over the catchment areas of the rivers considered which is imposed by climate change. Our interpretation is supported by Bouwer et al. (2006), who found no correlation between the time series of winter (December-February) discharges of 11 large European rivers, including the rivers Rhine, Elbe, Weser, and Meuse, with NAOI over 6 to 10 decades. They did find correlations between the frequency (number of days) of western circulation in winter and discharge. Shorthouse and Arnell (1999) also found strong relationships between winter river discharge and NAOI in Scandinavia and the Iberian Peninsula, but not in central Europe. In any case, the temporal developments of precipitation, freshwater discharge, and nutrient loads show long-term trends, superimposed by a 67 yr oscillation plus weather-induced variability.

\section{Consequences fOR THE Assessment OF EUTROPHICATION}

The process of eutrophication in the North Sea can be understood and assessed only when considering the effects of the changes of anthropogenic nutrient inputs on the continental coastal strip together with climatic changes, since the latter involve, e.g., changes of precipitation over the catchment areas. A strategy for assessing the past and present status of eutrophication in the coastal waters must consider not only mean states but also temporal variability, especially of river loads. Monitoring programs must be able to observe peak concentrations as well as singular events in the coastal waters. The scientific assessment of eutrophication must solve the following tasks, among others: to define criteria for endangered areas and nontolerable states, to develop monitoring strategies that enable the detection of such areas and states, and to find ways to separate anthropogenic from natural causes. The first task has been taken up, and detailed criteria were developed, according to which the European seas have been classified using existing data sets (Brockmann et al. 2002). The second and third tasks could be supported by using the time series of nutrient loads presented here. 
The second task faces the problem of ensuring sufficient observational resources for covering the seas with the necessary resolution in time and space. The temporal resolution must be more in the range of days to one week rather than months. The OSPAR nutrient monitoring program (OSPAR 2003) and its related monitoring guidelines were unified based on agreed harmonized assessment criteria, but the time and space scales they suggest are too large in our view. We argue that for this task simulation models should be used that take up the time series of river loads like the ones we presented as input and forcing variables. In this way the temporal and regional distribution of problem areas in the North Sea could be investigated for past and possibly also future scenarios. One important problem has to be solved first. The time series of the loads have to be corrected for retention of nutrients in the estuaries before performing the outlined model investigations.

For the open North Sea a conceptual framework exists in the form of (with respect to biology still relatively simple) simulation models, which seem to be the only tool for separating the effects of several agents acting in parallel on different scales with high variability. Model simulations can help to understand past eutrophication by hindcasts, and they can indicate which temporal and spatial resolution is necessary (in observational grids and models) to resolve the important events.

Pätsch and Radach (1997) attempted the reconstruction of the eutrophication of the North Sea for the period 1955-1993 using simulations with a relatively simple ecosystem model. They used the time series of daily river loads presented here as forcing functions, but only for the period 19771993, and loads from other sources (Anonymous 1992; Lenhart et al. 1996). In this way, they introduced the large observed variability of nutrient inputs to the North Sea into the model. Due to the observational gaps before this period they had to supplement the time series by estimates for the years 1955-1976 (Bennekom et al. 1975; Postma 1978; Nelissen and Steffels 1988) to enable a 40-yr run. Using these forcing data they were able to reproduce the decadal development of eutrophication in the North Sea during 1955-1993 with some success. A model comparison (OSPAR et al. 1998) showed that the use of these realistic riverine nutrient inputs in the decadal simulation by Pätsch and Radach (1997) gave results closest to observations in the continental coastal zone of the North Sea. Pätsch and Radach (1997) as well as Lenhart et al. (1997) showed that the coastal ecosystem reacted with only short time delays to the strongly variable river inputs. This is an important aspect for the design of monitoring programs and the assessment of eutrophication.

The third task can hardly be achieved by monitoring programs. The mixture of anthropogenic and climatic influences on the coastal waters can probably only be unravelled and explained, perhaps also even be hindcasted, by models simulating alternative scenarios in order to assess the individual roles of the different influences (Lenhart et al. 1997).

Our time series of daily discharges and nutrient river loads from the European continental rivers for 1977-2000 are suitable as forcing for decadal model simulations. The properties of eutrophication as defined in official documents of European authorities are based on time scales of several months (averaged over many years) and regions of some $100 \mathrm{~km}$ extension. These scales are too large to detect event-like features of eutrophication. Model simulations using a sufficiently resolved grid could show how the high variability of the nutrient loads would create temporal and spatial variability in the coastal waters. Their results could then be evaluated according to the guidelines from OSPAR (2001, 2002) to pinpoint critical time ranges and areas, probably better than those derived from the observations alone.

A precondition for quantifying the anthropogenic enrichment of nutrients in the coastal zone by simulation models is the knowledge (or estimate) of pristine conditions in the past. For the North Sea, Howarth et al. (1996) estimated the ratio of current riverine $\mathrm{N}$ export to pristine $\mathrm{N}$ river export to be 6.3 to 19.1. Pätsch and Radach (1997) extrapolated the loads backwards to 1955 , which resulted in a factor of 3.3 for TN and 9.8 for TP when comparing the years 1980 and 1955 .

The duration of our time series from 1977 to 2000 is not long enough to reach into these decades of pristine conditions, as for instance the time series of observed nitrate flux for the Mississippi River does, which started in the mid 1950s (McIsaac et al. 2002). Up to now the observed time series had to be extrapolated into the past on a vague database (Pätsch and Radach 1997). New methods, like applications of the $\delta^{15} \mathrm{~N}$ method by Voß and Struck (1997) and Emeis et al. (2002), may help to reconstruct the temporal development of $\mathrm{N}$ loads. This would improve the modelling approach for discriminating the natural from anthropogenic causes of eutrophication. In cases where no continuous time series of observations are available, modelling of riverine nutrient inputs may solve the problem. Processbased river modelling is now being developed (e.g., Andersson and Arheimer 2003; Behrendt et al. 2005). 


\section{ACKNOWLEDGMENTS}

We thank Ms. S. Asmus (Deutscher Wetterdienst, Hydrometeorologie, Koblenz) for providing the rain data, and Prof. H. Grassl (Max-Planck-Institut für Meteorologie, Hamburg) for helping to find the appropriate data sets. We thank our colleague Susan Beddig very much for improving the English.

\section{Literature Cited}

ANDERsson, L. AND B. ARHEIMER. 2003. Modelling of human and climatic impact on nitrogen load in a Swedish river 1885-1994. Hydrobiologia 497:63-77.

ANONYMOUs. 1992. Guidance Document for the NSTF Modelling Workshop 6-8 May 1992. Rijkswaterstaat (RWS), DirectoraatGeneraal. The Hague, The Netherlands.

ANONYMOUS. 1998. Gewässerüberwachungssystem Niedersachsen (GÜN) - Gütemeßnetz Fließgewässer: Meßstrategie und Meßnetzkonzeption. Niedersächsisches Umweltministerium und Niedersächsisches Landesamt für Ökologie. Hannover, Germany.

Baretta, J. W., W. EbenhöH, ANd P. Ruardi. 1995. The European Regional Seas Ecosystem Model (ERSEM), a complex marine ecosystem model. Netherlands Journal of Sea Research 33:233-246.

Baretta-Bekker, J. G. and J. W. Baretta. 1997. European Regional Seas Ecosystem Model (ERSEM) II. Journal of Sea Research 38:169-436.

Behrendt, H. 2004. Past, present and future changes in catchment fluxes. EUROCAT D 4.1 and 4.2. EUROCAT Project WD 14. Brussels, Belgium.

Behrendt, H., J. Van Gils, H. Schreiber, And M. Zessner. 2005. Point and diffuse nutrient emissions and loads in the transboundary Danube river basin. Large Rivers 16:221-247.

Bennekom, A. J. v., W. W. C. Gieskes, and S. B. Tijssen. 1975. Eutrophication of Dutch coastal waters. Proceedings of the Royal Society of London, Series B. Biological Sciences 189:359374 .

Bouwer, L. M., J. E. VermaAt, and J. C. J. H. Aerts. 2006. Winter atmospheric circulation and river discharge in northwest Europe. Geophysical Research Letters 33:L06403, 10.1029/ 2005 GL025548.

Boumman, A. F., G. Van Drecht, J. M. Knoop, A. H. W. Beusen, AND C. R. MEINARDI. 2005. Exploring changes in river nitrogen export to the world's ocean. Global Biochemical Cycles 19: GB1002, doi:10.1029/2004GB002314.

Brockmann, U., B. Heyden, M. Schütt, A. Starke, and D. Topcu. 2002. Assessment criteria for eutrophication areas - Emphasis German Bight. Umweltbundesamt Texte 48:1-109.

Carlson, H. 1986. Quality status of the North Sea. Deutsche Hydrographische Zeitschrift, Ergänzungsheft Reihe B 16:1-424.

Daмm, P. E. 1997. Die saisonale Salzgehalts- und Frischwasserverteilung in der Nordsee und ihre Bilanzierung. Berichte aus dem Zentrum für Meeres- und Klimaforschung, Reihe B: Ozeanographie 28. Universität Hamburg, Hamburg, Germany.

Dickson, R., J. Lazier, J. Meincke, P. Rhines, And J. Swift. 1996. Long-term coordinated changes in the convective activity of the North Atlantic. Progress in Oceanography 38:241-295.

Dickson, R. R., J. Meincke, S. A. Malmberg, and A. Lee. 1988. The "great salinity anomaly" in the northern North Atlantic 19681982. Progress in Oceanography 20:103-151.

European EnVIRONMENTAL Agency (EEA). 2005. Source appointment of nitrogen and phosphorus inputs into the aquatic environment. European Environmental Agency, Copenhagen, Denmark.

Emeis, K., C. Christiansen, K. Edelvang, S. Jähmlich, J. Kozuch, M. Laima, T. Leipe, A. Löffler, L. C. Lund-Hansen, A. Miltner, K. Pazdro, J. Pempkowiak, G. B. Shimmield, T. Shimmield, J. Smith, M. Voss, AND G. WitT. 2002. Material transport from the nearshore to the basinal environment in the southern Baltic
Sea II: Synthesis of data on origin and properties of material. Journal of Marine Systems 35:151-168.

Fock, H. O. 2003. Changes in the seasonal cycles of inorganic nutrients in the coastal zone of the southeastern North Sea from 1960 to 1997: Effects of eutrophication and sensitivity to meteoclimatic factors. Marine Pollution Bulletin 46:1434-1449.

Galloway, J. N., R. W. Howarth, A. F. Michaels, S. W. Nixon, J. M. Prospero, and F. J. Dentener. 1996. Nitrogen and phosphorus budgets of the North Atlantic Ocean and its watershed. Biogeochemistry 35:3-25.

Gazeau, F., S. V. Smith, B. Gentili, M. Frankignoulle, and J.-P. GATTUSO. 2004. The European coastal zone: Characterization and first assessment of ecosystem metabolism. Estuaries, Coastal and Shelf Science 60:673-694.

Greatbatch, R. J. 2000. The North Atlantic Oscillation. Stochastic Environmental and Risk Assessment 14:213-242.

Grimvall, A., P. Stalnacke, AND A. TONDERSKI. 2000. Time scales of nutrient losses from land to sea - A European perspective. Ecological Engineering 14:363-371.

Heath, M. R., A. C. Edwards, J. Pätsch, and W. R. Turrell. 2002. Modelling the behaviour of nutrient in the coastal waters of Scotland. Report of the Fisheries Research Services 10. Fisheries Research Services, Aberdeen, Scotland.

HiCKEL, W. 1998. Temporal variability of micro- and nanoplankton in the German Bight in relation to hydrographic structure and nutrient changes. ICES Journal of Marine Science 55:600-609.

Hickel, W., J. Berg, and K. Treutner. 1992. Variability in the biomass in the German Bight near Helgoland, 1980-1990. ICES Marine Science Symposia 195:249-259.

Hickel, W., P. Mangelsdorf, and J. Berg. 1993. The human impact in the German Bight: Eutrophication during three decades (1962-1991). Helgoländer Meeresuntersuchungen 47:243263.

Howarth, R. W., G. Billen, D. Swaney, A. Townsend, N. Jaworski, K. Lajtha, J. A. Downing, R. Elmgrem, N. Caraco, T. Jordan, F. Berendse, J. Freney, V. Kudeyarov, P. Murdoch, and Z. Zhu. 1996. Regional nitrogen budgets and riverine $\mathrm{N}$ and $\mathrm{P}$ fluxes for the drainages to the North Atlantic Ocean: Natural and human influences. Biogeochemistry 35:75-139.

Hurrell, J. W. 1995. Decadal trends in the North Atlantic Oscillation: Regional temperatures and precipitation. Science New Series 269:676-679.

Hurrell, J. W. AND H. VAN LOON. 1997. Decadal variations in climate associated with the North Atlantic Oscillation. Climatic Change 36:301-326.

IbrekK, H. O., J. Molvaer, AND B. FAafeng. 1991. Nutrient loading to Norwegian coastal waters and its contribution to the pollution of the North Sea. Water Science and Technology 24: 239-249.

JICKELLS, T. D. 1998. Nutrient biogeochemistry of the coastal zone. Science 281:217-222.

Kempe, S. 1995. Coastal seas: A net source or sink of atmospheric carbon dioxide? LOICZ/R\&C/95-1, LOICZ, Texel, The Netherlands.

Lenhart, H.-J. AND J. Pätsch. 2001. Daily nutrient loads of the European continental rivers for the years 1977-1998. Berichte aus dem Zentrum für Meeres- und Klimaforschung; Reihe B: Ozeanographie 40. Institut für Meereskunde, Hamburg, Germany.

Lenhart, H.-J., J. PÄtsch, AND G. Radach. 1996. Daily nutrient loads for the European continental rivers for the years 19771993. Berichte aus dem Zentrum für Meeres- und Klimaforschung; Reihe B: Ozeanographie 22. Institut für Meereskunde, Hamburg, Germany.

LENHART, H.-J., G. RADACH, AND P. RUARDIJ. 1997. The effects of river input on the ecosystem dynamics in the continental coastal zone of the North Sea using ERSEM. Journal of Sea Research 38:249-274.

Littlewood, I. G., C. D. Watts, and J. M. Custance. 1998. Systematic application of United Kingdom river flow and 
quality databases for estimating annual river mass loads (19751994). The Science of the Total Environment 210:21-40.

LozAn, J. L. AND H. Kausch. 1996. Warnsignale aus den Flüssen. Verlag Paul Parey, Berlin, Germany.

McisaAc, G. F., M. B. David, G. Z. Gertner, and D. A. Goolsby. 2002. Nitrate flux in the Mississippi River. Nature 414:166-167.

Moll, A. AND G. RADACH. 2003. Review of three-dimensional ecological modelling related to the North Sea shelf system - Part 1: Models and their results. Progress in Oceanography 57:175-217.

Nelissen, P. H. M. AND J. Steffels. 1988. Eutrophication in the North Sea. NIOZ Rapport 4. Netherlands Institute of Sea Research, Texel, The Netherlands.

Nixon, S. W., J. W. Ammerman, L. P. Atkinson, V. M. Berounsky, G. Billen, W. C. Boicourt, W. R. Boynton, T. M. Church, D. M. Ditoro, R. Elmgren, J. H. Garber, A. E. Giblin, R. A. JahnKe, N. J. P. Owens, M. E. Q. Pilson, And S. P. Seitzinger. 1996. The fate of nitrogen and phosphorus at the land-sea margin of the North Atlantic Ocean. Biogeochemistry 35:141-180.

North Sea Task Force. 1993. North Sea Quality Status Report 1993, Oslo and Paris Commission (OSPAR). Olsen and Olsen, Fredensborg, Denmark.

Oslo AND PARIS COMMISSION (OSPAR). 2000. Quality Status Report 2000 - Region II Greater North Sea. Oslo and Paris Commission, London, U.K.

OSLO AND PARIS COMmission (OSPAR). 2001. EUC 00/3/3, Annex 2, Appendix 3, Tables B, update June 2001. EUC 00/3/3. Oslo and Paris Commission, London, U.K.

Oslo and Paris Commission (OSPAR). 2002. Proposal from ETG 2001 for draft common assessment criteria, their assessment levels and area classification within the Comprehensive Procedure of the Common Procedure. EUC 01/2/2. Oslo and Paris Commission, London, U.K.

OSLO AND PARIS COMMISSION (OSPAR). 2003. OSPAR integrated report 2003 on the eutrophication status of the OSPAR maritime areas based upon the first application of the Comprehensive Procedure. Oslo and Paris Commission, London, U.K.

Oslo and Paris Commission (OSPAR), M. Villars, , I. De VRies, M. Bokhorst, J. Ferreira, S. Gellers-Barkman, B. Kelly-Gerreyn, C. Lancelot, A. Menesguen, A. Moll, J. PÄtsch, G. Radach, M. Skogen, H. Solland, E. Svendsen, and H. J. Vested. 1998. Report of the ASMO modelling workshop on eutrophication Issues, 5-8 November 1996, The Hague, The Netherlands. Oslo and Paris Commission, The Hague, The Netherlands.

PÄTSCH, J. AND H.-J. LenhaRT. 2004. Daily loads of nutrients, total alkalinity, dissolved inorganic carbon and dissolved organic carbon of the European continental rivers for the years 19772002. Berichte aus dem Zentrum für Meeres- und Klimaforschung; Reihe B: Ozeanographie 48. Institut für Meereskunde, Hamburg, Germany.

PÄTSCH, J. AND G. RADACH. 1997. Long-term simulation of the eutrophication of the North Sea: Temporal development of nutrients, chlorophyll and primary production in comparison to observations. Journal of Sea Research 38:275-310.

Postma, H. 1978. The nutrient contents of North Sea water: Changes in recent years, particularly in the Southern Bight. Rapport et Proces-verbaux des Reunions de Conseil Permanent International pour l'Exploration de la Mer 172:350-357.

Proctor, R., J. T. Holt, I. Allen, and J. Blackford. 2003. Nutrient fluxes and budgets for the northwest European shelf from a three-dimensional model. The Science of the Total Environment 314-316:769-785.

RADACH, G. 1992. Ecosystem functioning in the German Bight under continental nutrient inputs by rivers. Estuaries 15:477496.

RADACH, G. 1998. Quantification of long-term changes in the German Bight using an ecological development index. ICES Journal of Marine Science 55:587-599.
RADACH, G., J. BERG, AND E. HAGMEIER. 1990. Long-term changes of the annual cycles of meteorological, hydrographic, nutrient and phytoplankton time series at Helgoland and at LV ELBE 1 in the German Bight. Continental Shelf Research 10:305-328.

RADACH, G. AND H.-J. LENHART. 1995. Nutrient dynamics in the North Sea: Fluxes and budgets in the water column derived from ERSEM. Netherlands Journal of Sea Research 33:301-335.

RADACH, G. AND A. Moll. 2006. Review of three-dimensional ecological modelling related to the North Sea shelf system - Part 2: Model validation and data needs. Oceanography and Marine Biology. An Annual Review 44:1-60.

RHYTHER, J. H. AND W. M. DunSTAN. 1971. Nitrogen, phosphorous, and eutrophication in the coastal marine environment. Science 171:1008-1013.

ROSENBERG, R. 1985. Eutrophication - the future marine coastal nuisance? Marine Pollution Bulletin 16:227-231.

Seitzinger, S. P. ANd A. E. Giblin. 1996. Estimating denitrification in North Atlantic continental shelf sediments. Biochemistry 35: 235-260.

Shorthouse, C. A. And N. W. ARnell. 1999. The effects of climatic variability on spatial characteristics of European river flows. Physics and Chemistry of the Earth B 24:7-13.

Stalnacke, P., A. Grimvall, C. Libiseller, M. Laznik, and I. KOKORITE. 2003. Trends in nutrient concentrations in Latvian rivers and the response to the dramatic change in agriculture. Journal of Hydrology 283:184-205.

Sündermann, J., G. Becker, P. Damm, D van den Eynde, A. Frohse, R. LaAne, W. van Leussen, T. Pohlmann, W. van Raaphorst, G. RADACH, H. SchultZ, AND M. Visser. 1996. Decadal variability on the northwest European Shelf. Deutsche Hydrographische Zeitschrift 48:365-400.

Thomas, H., Y. Bozec, H. DE BaAr, K. Elkalay, M. Frankignoulle, W. Kühn, H. Lenhart, A. Moll, J. Pätsch, G. Radach, L.-S. Schiettecatte, ANd A. Borges. 2006. Carbon and nutrient budgets of the North Sea. In, L. Atkinson, K. K. Liu, R. Quinones, and L. Talaue-McManus (eds.), Carbon and Nutrient Fluxes in Global Continental Margins. Springer, New York, In press.

Van Beusekom, J. E. E., P. Bot, J. Göbel, M. Hanslik, H.-J. Lenhart, J. Pätsch, L. Peperzak, T. Petenati, and K. Reise. 2005. Eutrophication. Wadden Sea Ecosystem 19:141-154.

Van Beusekom, J. E. E., U. H. Brockmann, K. H. Hesse, W. Hickel, K. Poremba, and U. Tillmann. 1999. The importance of sediments in the transformation and turnover of nutrients and organic matter in the Wadden Sea and German Bight. Deutsche Hydrographische Zeitschrift 51:245-266.

Van Beusekom, J. E. E. and S. Diel-Christiansen. 1994. A synthesis of phyto- and zooplankton dynamics in the North Sea environment. International Report June 1994. World Wide Fund For Nature (WWF). Hamburg, Germany.

Visser, M., S. Batten, G. Becker, P. Bot, F. Colijn, P. Damm, D. Danielssen, D van den eynde, L. Foyn, A. Frohse, G. Groeneveld, R. LaAne, W. van RaAphorst, G. Radach, H. SChultz, AND J. SÜNDERMAnN. 1996. Time series analysis of monthly mean data of temperature, salinity, nutrients, suspended matter, phyto- and zooplankton at eight locations on the Northwest European shelf. Deutsche Hydrographische Zeitschrift 48:299-323.

VOB, M. AND U. STRUCK. 1997. Stable nitrogen and carbon isotopes as indicators of eutrophication in the Oder River (Baltic Sea). Marine Chemistry 59:35-59.

WulfF, F., L. Rahm, and P. LARsson (eds.). 2001. A Systems Analysis of the Baltic Sea. Ecological Studies 148. Springer, Berlin, Germany.

Received, November 16, 2005

Revised, July 18, 2006

Accepted, August 18, 2006 
Reproduced with permission of the copyright owner. Further reproduction prohibited without permission. 